\title{
OsPHR3 affects the traits governing nitrogen homeostasis in rice
}

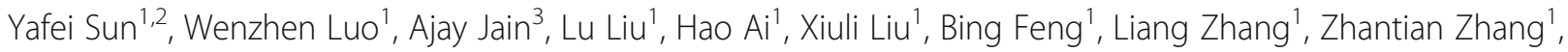 \\ Xu Guohua ${ }^{1}$ and Shubin Sun ${ }^{1 *}$
}

\begin{abstract}
Background: Phosphate $(\mathrm{Pi})$ and Nitrogen $(\mathrm{N})$ are essential macronutrients required for plant growth and development. In Arabidopsis thaliana (Arabidopsis), the transcription factor PHR1 acts as a Pi central regulator. PHL1 is a homolog of PHR1 and also plays a role in maintaining Pi homeostasis. In rice (Oryza sativa), OsPHR1-4 are the orthologs of PHR1 and have been implicated in regulating sensing and signaling cascades governing Pi homeostasis.

Results: Here the role of OSPHR3 was examined in regulating the homeostasis of $\mathrm{N}$ under different Pi regimes. Deficiencies of different variants of $\mathrm{N}$ exerted attenuating effects on the relative expression levels of OsPHR3 in a tissuespecific manner. For the functional characterization of OsPHR3, its Tos 17 insertion homozygous mutants i.e., osphr3-1, osphr3-2, and osphr3-3 were compared with the wild-type for various morphophysiological and molecular traits during vegetative (hydroponics with different regimes of $\mathrm{N}$ variants) and reproductive (pot soil) growth phases. During vegetative growth phase, compared with the wild-type, OsPHR3 mutants showed significant variations in the adventitious root development, influx rates of ${ }^{15} \mathrm{~N}_{-} \mathrm{NO}_{3}{ }^{-}$and ${ }^{15} \mathrm{~N}_{-} \mathrm{NH}_{4}{ }^{+}$, concentrations of total $\mathrm{N}_{1} \mathrm{NO}_{3}{ }^{-}$and $\mathrm{NH}_{4}{ }^{+}$in different tissues, and the relative expression levels of OsNRT1.1a, OsNRT2.4, OsAMT1;1, OsNia1 and OsNia2. The effects of the mutation in OSPHR3 was also explicit on the seed-set and grain yield during growth in a pot soil. Although Pi deficiency affected total $\mathrm{N}_{\text {and }} \mathrm{NO}_{3}^{-}$concentration, the lateral root development and the relative expression levels of some of the $\mathrm{NO}_{3}{ }^{-}$and $\mathrm{NH}_{4}{ }^{+}$transporter genes, its availability did not exert any notable regulatory influences on the traits governing $\mathrm{N}$ homeostasis.
\end{abstract}

Conclusions: OsPHR3 plays a pivotal role in regulating the homeostasis of $\mathrm{N}$ independent of Pi availability.

Keywords: Rice, Arabidopsis, Phosphate, Nitrogen variants, OsPHR3, Pi availability

\section{Background}

Rice (Oryza sativa L.) is the main dietary staple for more than half of the 7.5 billion populations in the world, of which $\sim 90 \%$ is consumed in Asia alone (www.irri.org/ rice-today). United Nations raises world population forecast to 9.8 billion people by 2050 due to escalated population growth particularly in Africa and India (www.un.org). According to FAO, world agriculture will thus face the daunting task of using scarce natural resources more efficiently and adapting to climate change for producing $\sim 70 \%$ more food for feeding additional

\footnotetext{
* Correspondence: sunshubin@njau.edu.cn

'State Key Laboratory of Crop Genetics and Germplasm Enhancement, Key Laboratory of Plant Nutrition and Fertilization in Low-Middle Reaches of the Yangtze River, Ministry of Agriculture, Nanjing Agricultural University, Nanjing 210095, China

Full list of author information is available at the end of the article
}

2.3 billion people by 2050 (www.fao.org). Since rice provides $27 \%$ and $20 \%$ of dietary energy supply and dietary protein intake, respectively in the developing world (www.fao.org), its sustainable production is increasingly becoming pivotal for global food security.

Nitrogen $(\mathrm{N})$ is a key component of important macromolecules such as nucleic acids, proteins and chlorophyll and constitutes $\sim 1.5-2 \%$ of plant dry matter [1]. N is taken up by plants as nitrate $\left(\mathrm{NO}_{3}{ }^{-}\right)$and ammonium $\left(\mathrm{NH}_{4}{ }^{+}\right)$with the former being the predominant form in most soils [2]. If $\mathrm{N}$ deficiency is rampant in rice growing soils, it will affect the growth and development of tillers and panicles and consequently the yield potential. Although $\mathrm{N}$-deficient soils are conventionally enriched with $\mathrm{N}$ fertilizers, their excessive usage is uneconomical for sustainable agriculture and also poses a serious threat to the environment [3]. In this context, 
manipulation of a specific molecular entity through biotechnological intervention is an economically viable and eco-friendly paradigm for engineering rice with higher $\mathrm{N}$ use efficiency [4]. Now, a repertoire of genes implicated in regulating acquisition, transportation and utilization of $\mathrm{N}$ in rice have been identified $[2,5]$. Studies also found that availability of phosphate $(\mathrm{Pi})$, an essential nutrient required for optimal growth and development of plants [6-8] exerted variable influence on the expression of some of the genes involved in the sensing and signaling cascades governing homeostasis of $\mathrm{N}$ in rice $[9,10]$.

Reverse genetics approaches have helped to identify several transcription factors (TFs) that extert regulatory influences on an array of functionally diverse genes involved in the maintenance of $\mathrm{N}$ and $\mathrm{Pi}$ homeostasis [2, 11]. TFs regulate the expression of the target genes by binding to the cis-regulatory specific sequences in their promoters [12]. The TF PHR1 (PHOSPHATE STARVATION RESPONSE 1), a homolog of PSR1 (PHOSPHATE STARVATION RESPONSE 1) in Chlamydomonas reinhardtii [13] was positionally cloned and characterized in Arabidopsis thaliana [14]. PHR1 has a predicted coiled-coil domain and binds as a dimer to an imperfect palindromic PHR1-specific binding sequence (P1BS; GNATATNC) presenting in the promoters of Pi-starvation induced genes [14]. PHR1 acts as a central regulatory TF, which controls spatiotemporal transcriptional activation and repression of several phosphate-starvation responsive (PSR) genes implicated in signaling and different metabolic pathways during Pi deficiency [15-21]. In addition, PHR1 also interacts with AtFer1 promoter enriched with P1BS during Pi deficiency [22]. AtFer1 encodes plastid-located ferritin, a protein nanocage which can store up to 4,500 atoms of $\mathrm{Fe}^{3+}$ in its interior that are released in a controlled fashion [23]. In Arabidopsis, PHR1 also plays a pivotal role in regulating sulfate flux from shoot to root during Pi deprivation [24] and exerts influence on the crosstalk between $\mathrm{Pi}$ and $\mathrm{Zn}$ [25]. These studies thus highlighted a key role of PHR1 in regulating the homeostasis of Pi and other essential nutrients. Further, a search for T-DNA mutations at PHR1-related genes in public databases led to the identification of PHR1-LIKE1 (PHL1, At5g29000). Pi accumulation was significantly higher in PHR1-overexpressing transgenic lines compared with phl1 mutant, and it was significantly lower in the double mutant phrlphl1 compared with the latter, which suggested partial functional redundancy between PHR1 and PHL1 [16]. In Arabidopsis, PHL2 and PHL3 are the homologs of PHL1 and of these PHL2 play a pivotal role in regulating transcriptional response to Pi deficiency and is functionally redundant with PHR1 [21]. In rice, phylogenetic and mutational analyses revealed functional redundancy across PHR1 orthologs (OsPHR1-3) and together they formed a network for regulating sensing and signaling cascades governing Pi homeostasis [26, 27]. Pi-starvation induced OsPHR4 mediates Pi homeostasis and plays a pivotal role in the regulation of downstream PSR genes [28]. Although the expression of OsPHR3 is induced by Pi starvation, its mutation does not exert any significant influence on the $\mathrm{Pi}$ concentration and on the expression of downstream PSR genes [27]. The study also revealed that OsPHR3 exhibited lowest binding affinity towards P1BS but still plays a role in growth of Pi-deprived Arabidopsis. However, it is not known whether OsPHR3 plays a role in exerting a regulatory influence on the morphophysiological and molecular traits governing $\mathrm{N}$ homeostasis in a manner dependent or independent of Pi availability.

Here, in our study, we showed that OsPHR3 is responsive to different forms of $\mathrm{N}$ irrespective of Pi regimes. The silencing of OsPHR3 triggered wide-spectrum effects on different traits during vegetative and reproductive growth phases. Availability of Pi did not exert any notable effects on OsPHR3-mediated regulatory influence on $\mathrm{N}$ homeostasis under different $\mathrm{N}$ variants and the lateral root development responses under different $\mathrm{NO}_{3}{ }^{-}$treatments.

\section{Results \\ OsPHR3 is responsive to different forms of $\mathrm{N}$}

TBLASTN (http://www.ncbi.nlm.nih.gov/BLAST) was employed for searching the homolog of Arabidopsis AtPHL1 (At5g29000) in rice, which resulted in the identification of OsPHL1 on the chromosome 2. However, this gene has been reported in 2015, which named as OsPHR3 (LOC_Os02g04640) [27]. Thus we changed OsPHL1 to OsPHR3. OsPHR3 is a MYB coiled-coil (MYB-CC) domain-containing TF (http://www.ebi.ac.uk/ interpro/). OsPHR3's orthologs are AtPHR1 and AtPHL1-3 in Arabidopsis $[14,16,21]$ and paralogs are OsPHR1-4 in rice [26-28]. The amino acid sequence identity of OsPHR3 ranged from 56.96\% with OsPHR4 to $26.06 \%$ with OsPHR2 (Additional file 1). Multiple amino acid sequence alignment of OsPHR3 with other MYB-CC family members (AtPHR1, AtPHL1, OsPHR1, 2 and 4) revealed the conserved MYB helix-turn-helix (MYB-HTH) and MYB-CC domains (Additional file 1). The qRT-PCR was employed to determine the relative expression levels of OsPHR3 in the shoot and root of the wild-type rice seedlings grown hydroponically in a medium supplemented with different forms and concentrations of $\mathrm{N}\left(\mathrm{H} \mathrm{NH}_{4}{ }^{+} / \mathrm{L} \mathrm{NH}_{4}{ }^{+}, \mathrm{H} \mathrm{NO}_{3}{ }^{-} / \mathrm{L} \mathrm{NO}_{3}{ }^{-}\right.$and + $\mathrm{N} /-\mathrm{N},+\mathrm{N}$ and $-\mathrm{N}$ indicate $2.5 \mathrm{mM}$ and $0.25 \mathrm{mM} \mathrm{N}$, respectively) (Fig. 1). The relative expression levels of OsPHR3 were significantly reduced in the root under $\mathrm{L}$ $\mathrm{NH}_{4}{ }^{+}$, and both shoot and root under $\mathrm{L} \mathrm{NO}_{3}{ }^{-}$compared with their corresponding $\mathrm{H} \mathrm{NH}_{4}{ }^{+}$and $\mathrm{H} \mathrm{NO}_{3}{ }^{-}$(Fig. 1a). Further, the relative expression levels of OsPHR3 were significantly attenuated in $-\mathrm{N}$ shoot and root compared with $+\mathrm{N}$ seedling (Fig. 1b). It was evident from the 


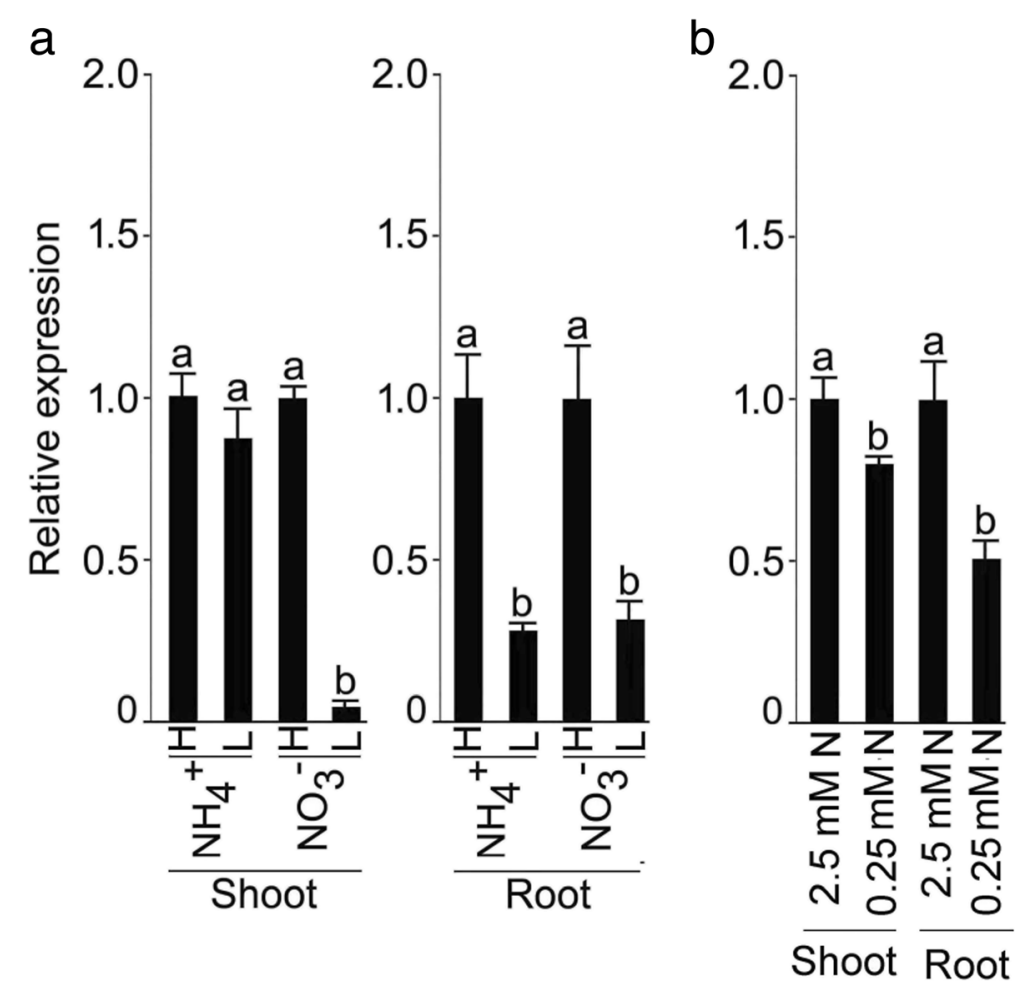

Fig. 1 Tissue-specific differential relative expression levels of OsPHR3 during growth under different regimes of $\mathrm{N}$ variants. Seeds of the wild-type were grown hydroponically in IRRI solution for 2 weeks, starved for $\mathrm{N}$ for $3 \mathrm{~d}$ and then supplied for $24 \mathrm{~h}$ with nutrient solution containing high $\mathrm{NH}_{4}^{+}\left(\mathrm{H} \mathrm{NH}_{4}^{+}, 5 \mathrm{mM}\right)$, low $\mathrm{NH}_{4}{ }^{+}\left(\mathrm{L} \mathrm{NH}_{4}^{+}, 0.25 \mathrm{mM}\right)$, high NO${ }_{3}^{-}\left(\mathrm{H} \mathrm{NO}_{3}{ }^{-}, 5 \mathrm{mM}\right)$, low NO${ }_{3}^{-}\left(\mathrm{L} \mathrm{NO}_{3}{ }^{-}, 0.25 \mathrm{mM}\right), 2.5 \mathrm{mM} \mathrm{N}^{-}\left(1.25 \mathrm{mM} \mathrm{NH}_{4}^{+}\right.$and $1.25 \mathrm{mM} \mathrm{NO}_{3}{ }^{-}$) ) and $0.25 \mathrm{mM}\left(0.125 \mathrm{mM} \mathrm{NH}_{4}{ }^{+}\right.$and $\left.0.125 \mathrm{mM} \mathrm{NO}_{3}{ }^{-}\right)$. Root and shoot were harvested for the qRT-PCR analysis of the relative expression levels of OsPHR3 in (a) high and low $\mathrm{NH}_{4}{ }^{+}$or $\mathrm{NO}_{3}{ }^{-}$and (b) $2.5 \mathrm{mM} \mathrm{N}$ and $0.25 \mathrm{mM} \mathrm{N}$ conditions. Actin (OsRac); LOC_Os03g50885) was used as an internal control and the values for $\mathrm{H} \mathrm{NH}_{4}{ }^{+}, \mathrm{H} \mathrm{NO}_{3}{ }^{-}$and $+\mathrm{N}$ were normalized to 1. Values are means $\pm \mathrm{SE}(n=3)$ and different letters on the histograms indicate that the values differ significantly $(P<0.05$, one-way ANOVA)

results that different forms and regimes of $\mathrm{N}$ exerted significant influence on the relative expression levels of OsPHR3 in a tissue-specific manner.

\section{Silencing of OsPHR3 affects vegetative growth under different regimes and forms of $\mathrm{N}$ and reproductive growth at grain-filling stage}

Three homozygous OsPHR3 mutants in the Nipponbare background (osphr3-1, osphr3-2 and osphr3-3) were obtained from the rice Tos 17 insertion mutant database (https://tos.nias.affrc.go.jp) (Additional file 2). There was a Tos17 insertion in the first (osphr3-2 and osphr3-3) and the last (osphr3-1) exon of OsPHR3 (Additional file 2). Semi-quantitative RT-PCR analysis revealed the absence of OsPHR3 transcript in these mutants (Additional file 2). These knock-out mutants were then compared with the wild-type for the effects of different $\mathrm{N}$ forms and regimes on the vegetative traits (biomass and an average length of the adventitious roots) when grown hydroponically, and also on the reproductive traits (per cent seed-set and grain yield/plant) during growth in a pot soil up to grain-filling stage (Fig. 2). There were no apparent effects on the growth response of the mutant (osphr3-1, osphr3-2 and osphr3-3) seedlings compared with the wild-type under both $+\mathrm{N}$ and $-\mathrm{N}$ conditions $(+\mathrm{N}$ and $-\mathrm{N}$ indicate $2.5 \mathrm{mM}$ and $0.25 \mathrm{mM} \mathrm{N}$, respectively) (Fig. 2a). Although shoot biomass of the mutants (osphr3-1, osphr3-2 and osphr33) was comparable with the wild-type irrespective of $\mathrm{N}$ regimes, their root biomass was significantly lower than the wild-type under both $+\mathrm{N}(\sim 27-30 \%)$ and $-\mathrm{N}(\sim 27-33 \%)$ conditions (Fig. 2b). Root system architecture and the primary root length of the mutants (osphr3-1and osphr3-2) were comparable with the wild-type under both $\mathrm{H} \mathrm{NO}_{3}{ }^{-}$ and $\mathrm{L} \mathrm{NO}_{3}{ }^{-}$conditions (Fig. 2c). However, an average length of the adventitious roots of the mutants (osphr31and osphr3-2) revealed significant reductions under $\mathrm{H}$ $\mathrm{NO}_{3}{ }^{-}(\sim 52-62 \%), \mathrm{L} \mathrm{NO}_{3}^{-}(\sim 51-52 \%)$ (Fig. 2d) and $\mathrm{L}$ $\mathrm{NH}_{4}{ }^{+}(\sim 23 \%)$ (Additional file 3) conditions compared with the wild-type. To further determine the role of OsPHR3, if any, during the reproductive growth phase, the wild-type and the mutants (osphr3-1, osphr3-2 and osphr3-3) were grown in a pot soil up to the grain-filling stage (Fig. 2e-g). The growth of the panicle was retarded in the mutants compared with the wild-type (Fig. 2e), 


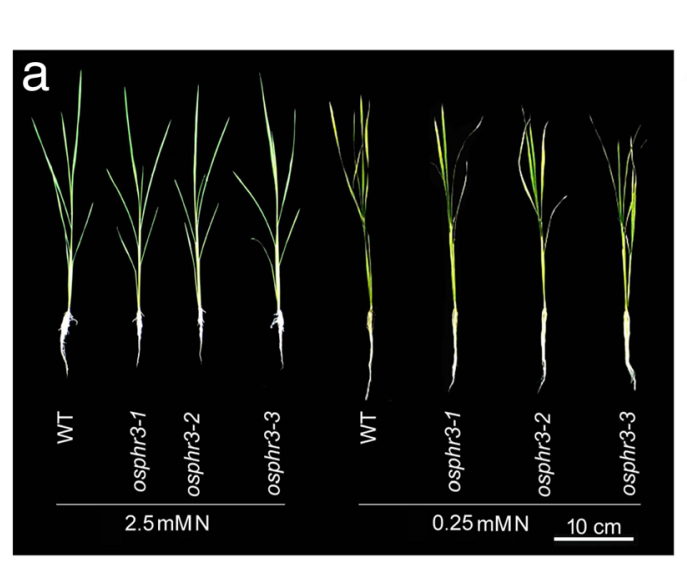

$\mathrm{b}_{0.25}$

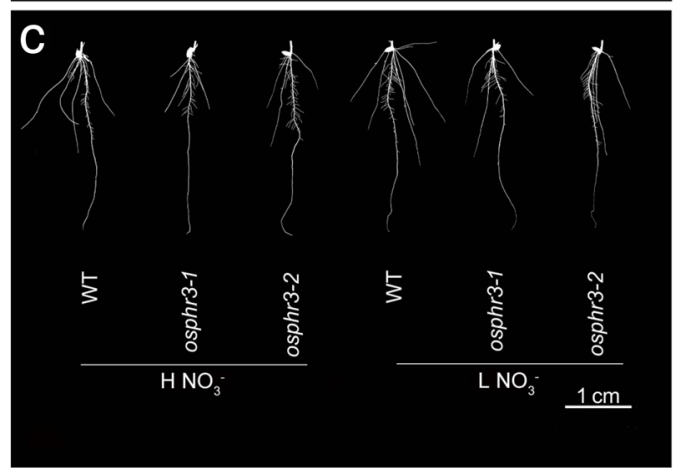

d 10
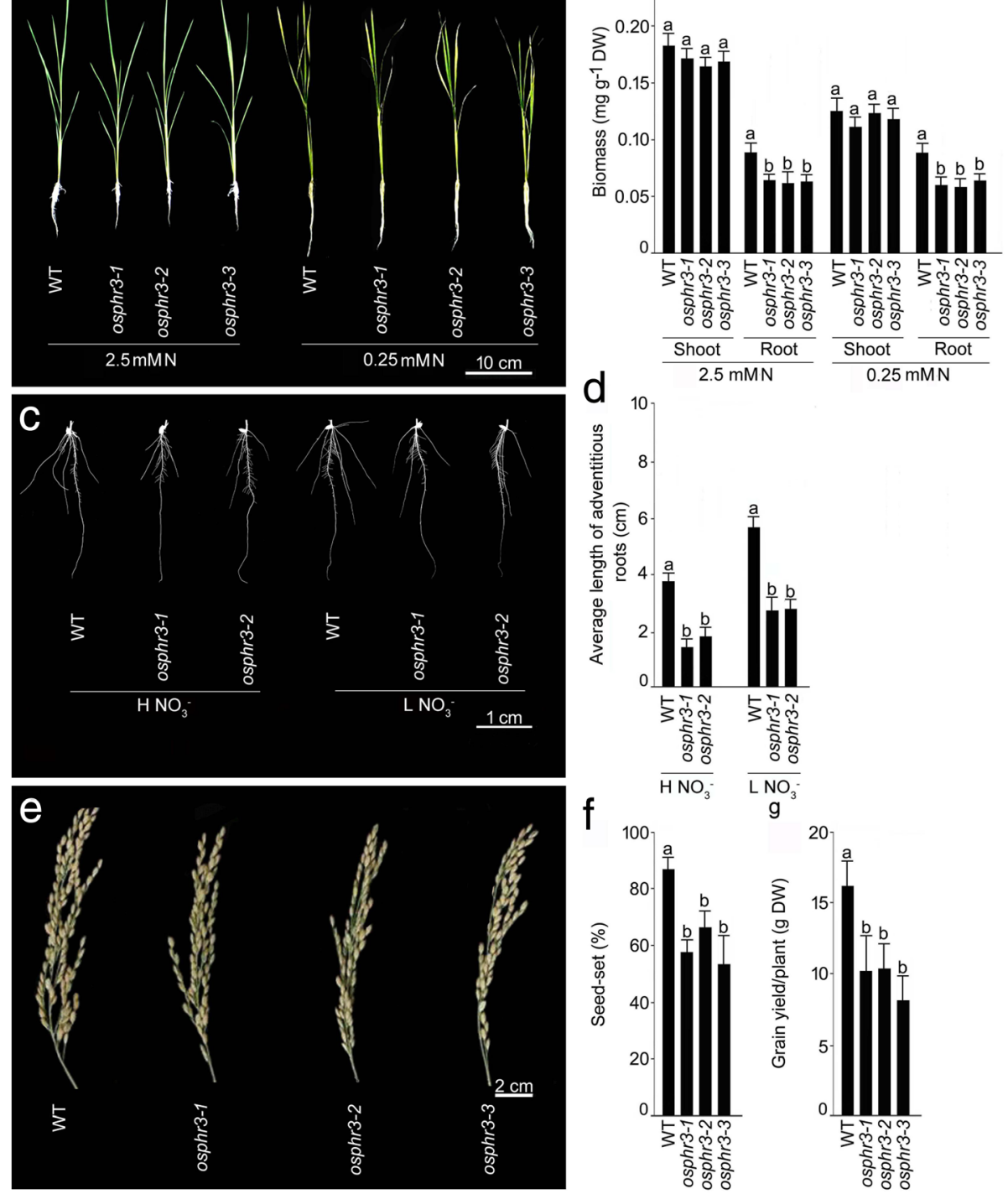

Fig. 2 Mutation in OsPHR3 affects vegetative and reproductive traits under different $\mathrm{N}$ and $\mathrm{NO}_{3}{ }^{-}$regimes. Seeds of the WT and OsPHR3 mutants (osphr3-1, osphr3-2 and osphr3-3) were grown hydroponically in IRRI solution for 2 weeks. Seedlings were then transferred to (a, b) $2.5 \mathrm{mM} \mathrm{N}$ and $0.25 \mathrm{mM} \mathrm{N}$ and $(\mathbf{c}, \mathbf{d}) \mathrm{H} \mathrm{NO}_{3}$ and $\mathrm{L} \mathrm{NO}_{3}{ }^{-}$media for $7 \mathrm{~d}$. e, $\mathbf{f} \mathrm{WT}$ and the mutants were also grown in a pot soil for 17 weeks (grain-filling stage). Phenotypes of the (a) seedlings, (c) root system architecture and (e) panicles were observed. Data are presented for (b) biomass, (d) average length of adventitious roots, (f) per cent seed-set and ( $\mathbf{g})$ grain yield/plant. Values in $(\mathbf{b}$, $\mathbf{d}$ and $\mathbf{e})$ are means \pm SE $(n=5)$ and different letters on the histograms indicate that the values differ significantly $(P<0.05$, one-way ANOVA)

which was congruent with significant reductions in the per cent seed-set $(\sim 23-35 \%)$ (Fig. $2 \mathrm{f})$, and grain yield/ plant $(\sim 35-49 \%)$ (Fig. 2g). The results suggested a broad spectrum positive regulatory influence of OsPHR3 during both vegetative and reproductive growth phases of rice.

\section{Silencing of OsPHR3 affects $\mathrm{N}$ homeostasis}

The wild-type and the mutants (osphr3-1 and 3-2) were grown hydroponically under $+\mathrm{N}$ and $-\mathrm{N}$ condition for $7 \mathrm{~d}$ to determine the effects of the mutation in OsPHR3 on the concentrations of total $\mathrm{N}, \mathrm{NO}_{3}{ }^{-}$and $\mathrm{NH}_{4}{ }^{+}$in the shoot and root of the seedlings $(+\mathrm{N}$ and $-\mathrm{N}$ indicate $2.5 \mathrm{mM}$ and $0.25 \mathrm{mM} \mathrm{N}$, respectively) (Fig. 3). There were no significant differences in the concentrations of $\mathrm{NO}_{3}{ }^{-}$in $-\mathrm{N}$ shoot, $\mathrm{NH}_{4}{ }^{+}$in $+\mathrm{N}$ and $-\mathrm{N}$ shoot and $+\mathrm{N}$ root of the wild-type and the mutants (Fig. 3a-c). However, the attenuating effects of the mutation in OsPHR3 were evident on the concentrations of total $\mathrm{N}$ in $+\mathrm{N}$ shoot $(\sim 9-11 \%)$ and $-\mathrm{N}$ shoot $(\sim 11-13 \%),+\mathrm{N}$ root $(\sim 30-38 \%)$ and $-\mathrm{N}$ root ( 27-30\%), $\mathrm{NO}_{3}{ }^{-}$in $+\mathrm{N}$ shoot $(\sim 26-30 \%),+\mathrm{N}$ root 


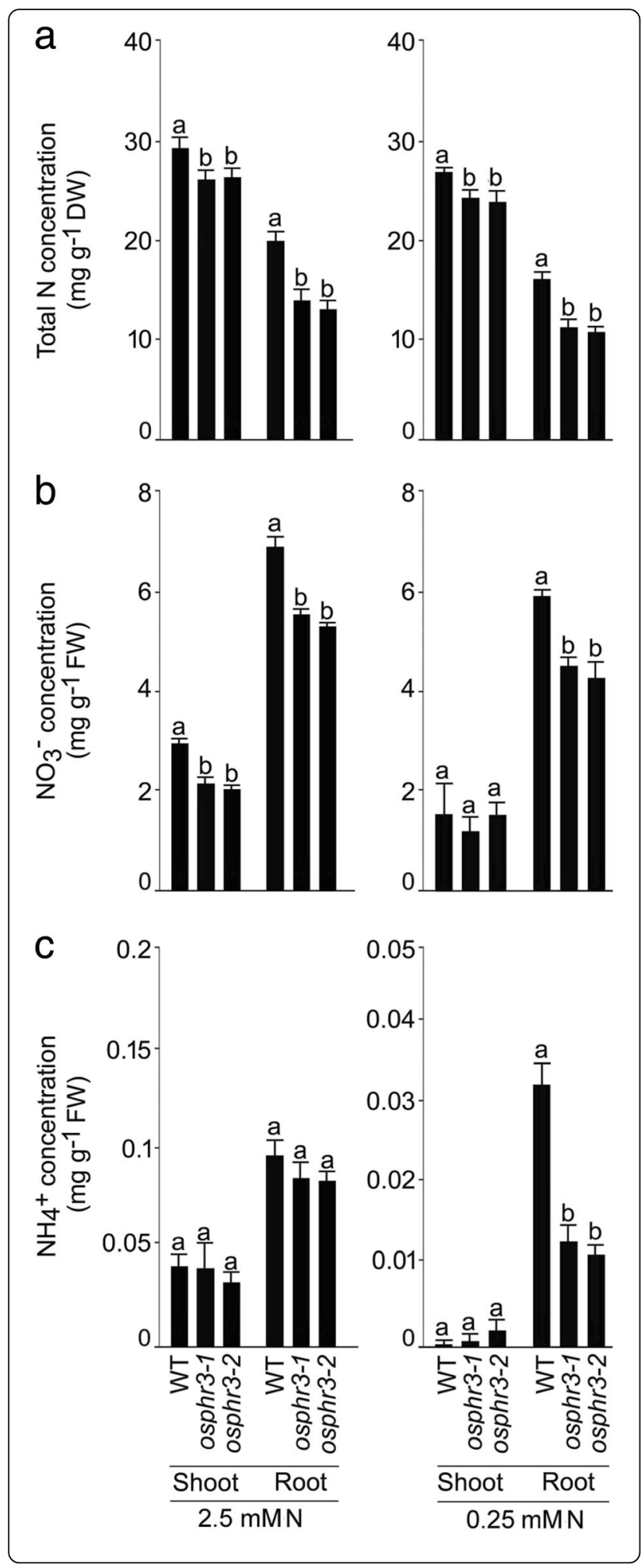

Fig. 3 Mutation in OsPHR3 affects total $\mathrm{N}_{1} \mathrm{NO}_{3}{ }^{-}$and $\mathrm{NH}_{4}{ }^{+}$ concentrations under different $\mathrm{N}$ regimes. Seeds of the $\mathrm{WT}$ and mutants (osphr3-1 and 3-2) were grown hydroponically in IRRI solution for 2 weeks, deprived of $\mathrm{N}$ for $3 \mathrm{~d}$ and then transferred to $2.5 \mathrm{mM} \mathrm{N}$ and $0.25 \mathrm{mM} \mathrm{N}$ media for $7 \mathrm{~d}$. Shoot and root were harvested. Data are presented for the concentration of (a) total $\mathrm{N},(\mathbf{b}) \mathrm{NO}_{3}{ }^{-}$and (c) $\mathrm{NH}_{4}{ }^{+}$. Values are means $\pm \operatorname{SE}(n=5)$ and different letters on the histograms indicate that the values differ significantly $(P<0.05$, one-way ANOVA)

$(\sim 19-23 \%)$ and $-\mathrm{N}$ root $(\sim 23-37 \%)$ and $\mathrm{NH}_{4}{ }^{+}$in $-\mathrm{N}$ root ( 60-64\%) (Fig. 3a-c). Further, the wild-type and the mutants (osphr3-1 and 3-2) were grown in a pot soil up to the maturity (grain harvest stage) to determine the effects of the mutation in OsPHR3 on the concentration of total $\mathrm{N}$ in different tissues at the reproductive stage (Additional file 4). Total $\mathrm{N}$ concentration was comparable in the 3rd leaf blade, culm, leaf sheath, panicle, significantly lower in the 6th leaf blade $(\sim 17-22 \%)$, and significantly higher in the 1 st leaf blade $(\sim 17-21 \%)$ and seed $(\sim 12-16 \%)$. Isotope assays were then employed for comparing the influx of $\mathrm{NO}_{3}{ }^{-}$and $\mathrm{NH}_{4}{ }^{+}$for $10 \mathrm{~min}$ and their subsequent translocation to the shoot after $24 \mathrm{~h}$ between the wild-type and the mutants (osphr3-1 and 3-2) grown hydroponically under different $\mathrm{N}$ regimes (Fig. 4). Compared with the wild-type, the mutants showed significantly lower influx rate of ${ }^{15} \mathrm{NO}_{3}{ }^{-}(\sim 12-17 \%)$ in $+\mathrm{N}$ root, ${ }^{15} \mathrm{NO}_{3}{ }^{-}(\sim 49-50 \%)$ and ${ }^{15} \mathrm{NH}_{4}{ }^{+}(\sim 25-27 \%)$ in $-\mathrm{N}$ root, while the corresponding values remained comparable of ${ }^{15} \mathrm{NH}_{4}{ }^{+}$in the $+\mathrm{N}$ root (Fig. 4a, c). Although the ratio (translocation) of ${ }^{15} \mathrm{NO}_{3}{ }^{-}$in $-\mathrm{N}$ plant and ${ }^{15} \mathrm{NH}_{4}{ }^{+}$in $+\mathrm{N}$ and $-\mathrm{N}$ plant in the wild-type and the mutants were comparable, the ratio of ${ }^{15} \mathrm{NO}_{3}{ }^{-}$in $+\mathrm{N}$ plant was significantly lower $(\sim 25-29 \%)$ in the mutants compared with the wild-type (Fig. 4b, d). In addition, the concentration of $\mathrm{NO}_{3}{ }^{-}$was assayed in the second young leaf blade (YLB) and fourth old leaf blade (OLB) at a five-leaf stage of the wild-type and mutants (osphr3-1 and osphr3-2) grown hydroponically under $\mathrm{H} \mathrm{NO}_{3}{ }^{-}$and $\mathrm{L} \mathrm{NO}_{3}{ }^{-}$condition for 7d (Fig. 5a). Compared with the wild-type, $\mathrm{NO}_{3}{ }^{-}$concentrations in the mutants were $\sim 59-85 \%$ and $\sim 37 \%$ higher in YLB under $\mathrm{H} \mathrm{NO}_{3}{ }^{-}$and $\mathrm{L} \mathrm{NO}_{3}{ }^{-}$, respectively. On the contrary, an opposite trend was observed in OLB, where the values were $\sim 45-71 \%$ and $\sim 16-33 \%$ lower under $\mathrm{H} \mathrm{NO}_{3}{ }^{-}$and $\mathrm{L} \mathrm{NO}_{3}{ }^{-}$, respectively. Finally, redistribution of $\mathrm{NO}_{3}{ }^{-}$from the older to younger leaf was assayed in the wild-type and the mutants (osphr3-1 and osphr3-2) by exposing the $\mathrm{N}$-starved oldest leaves to ${ }^{15} \mathrm{~N}_{-} \mathrm{NO}_{3}{ }^{-}$for $5 \mathrm{~h}$ (Fig. $5 \mathrm{~b}$ ). The mutants showed significantly higher $(\sim 84-125 \%)$ redistribution ratio of ${ }^{15} \mathrm{NO}_{3}{ }^{-}$compared with the wild-type. The results thus suggested the regulatory influence of OsPHR3 in the maintenance of homeostasis of diverse forms of $\mathrm{N}$ under different $\mathrm{N}$ regimes in a tissue-specific manner. 


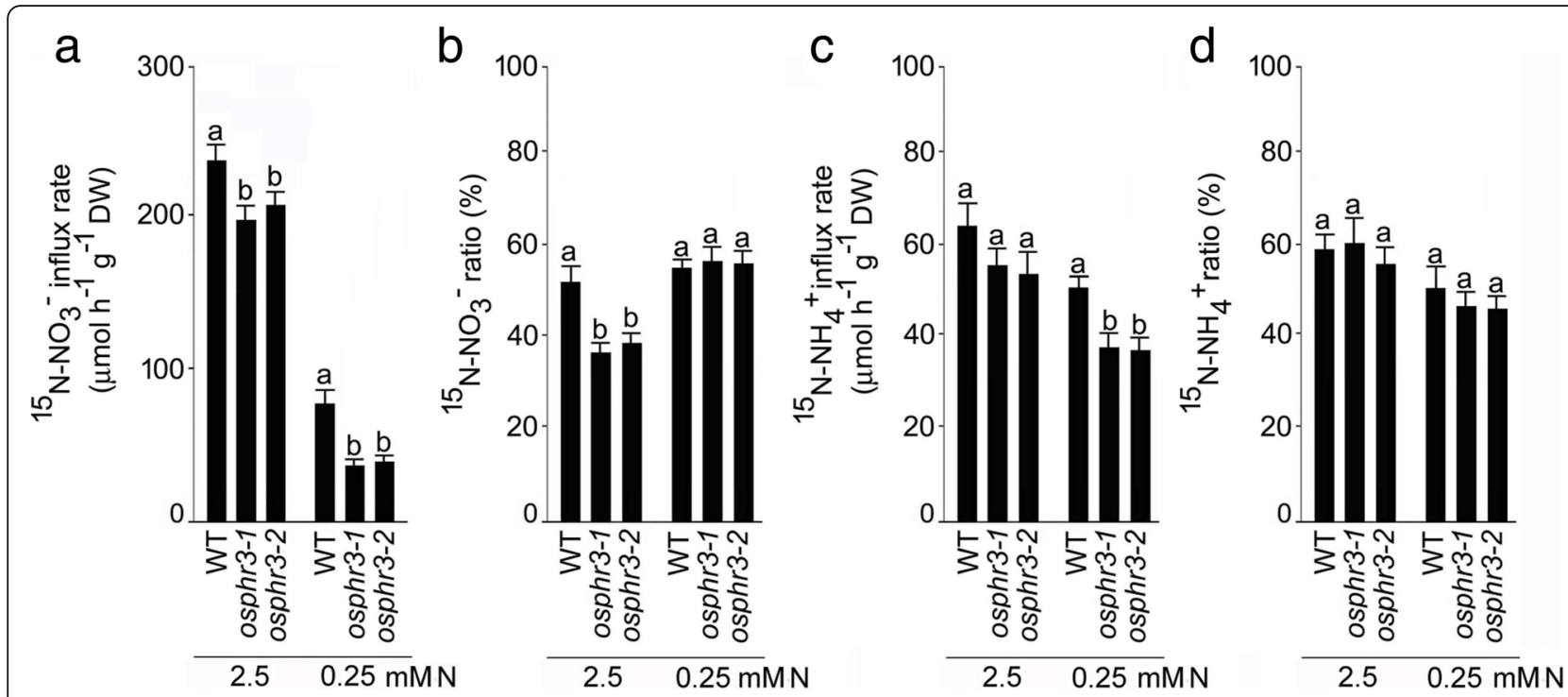

Fig. 4 Mutation in OsPHR3 affects influx and translocation of ${ }^{15} \mathrm{~N}_{-} \mathrm{NO}_{3}{ }^{-}$and ${ }^{15} \mathrm{~N}-\mathrm{NH}_{4}{ }^{+}$under different $\mathrm{N}$ regimes. Seeds of the WT and mutants (osphr3-1 and 3-2) were grown hydroponically in IRRI solution for 2 weeks and then deprived of $\mathrm{N}$ for $3 \mathrm{~d}$. Seedlings were then treated with ${ }^{15} \mathrm{~N}_{-} \mathrm{NO}_{3}{ }^{-}$and ${ }^{15} \mathrm{~N}_{-} \mathrm{NH}_{4}{ }^{+}$under $2.5 \mathrm{mM} \mathrm{N}$ and $0.25 \mathrm{mM} \mathrm{N}$ conditions for $10 \mathrm{~min}$ and $1 \mathrm{~d}$ for determining their influx and translocation, respectively. The influx rate of (a) ${ }^{15} \mathrm{~N}_{-} \mathrm{NO}_{3}{ }^{-}$and $(\mathbf{c}){ }^{15} \mathrm{~N}_{-} \mathrm{NH}_{4}{ }^{+}$. The translocation ratio of $(\mathbf{b}){ }^{15} \mathrm{~N}_{-} \mathrm{NO}_{3}{ }^{-}$and $(\mathbf{d}){ }^{15} \mathrm{~N}-\mathrm{NH}{ }_{4}^{+}$. Values are means $\pm \mathrm{SE}$ $(n=5)$ and different letters on the histograms indicate that the values differ significantly $(P<0.05$, one-way ANOVA)

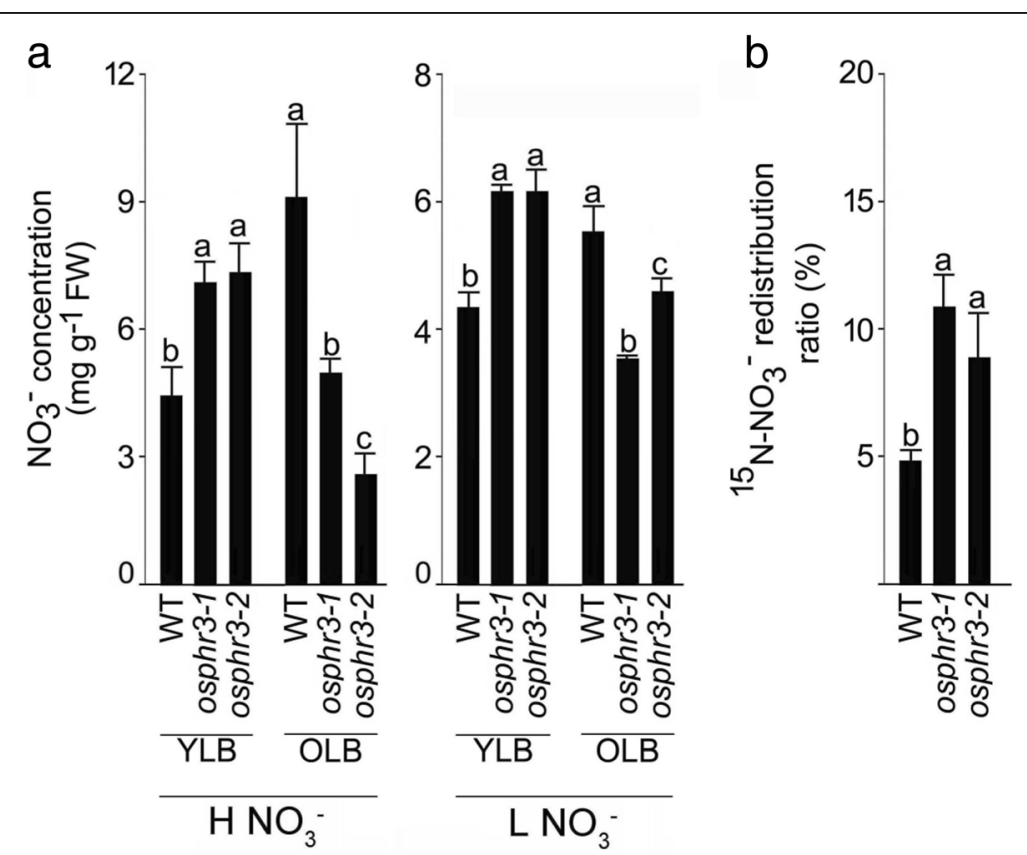

Fig. 5 Mutation in OsPHR3 affects concentration and redistribution of $\mathrm{NO}_{3}{ }^{-}$in young and old leaf blades. Seeds of the WT and mutants (osphr3-1 and 3-2) were grown hydroponically in IRRI solution for 3 weeks and then deprived of $\mathrm{N}$ for $3 \mathrm{~d}$. a Seedlings were then transferred to $\mathrm{H} \mathrm{NO}_{3}{ }^{-}$and $\mathrm{L}$ $\mathrm{NO}_{3}{ }^{-}$for $7 \mathrm{~d}$. Young leaf blade (YLB) and old leaf blade (OLB) were harvested and assayed for $\mathrm{NO}_{3}{ }^{-}$concentration. $\mathbf{b}$ For determining ${ }^{15} \mathrm{NO}_{3}{ }^{-}$ redistribution ratio, the oldest leaf blade of the WT and mutant seedlings were incubated in a solution containing ${ }^{15} \mathrm{~N}_{-} \mathrm{NO}_{3}{ }^{-}(5 \mathrm{mM})$ for $5 \mathrm{~h}$. values are means $\pm \operatorname{SE}(n=5)$ and different letters on the histograms indicate that the values differ significantly $(P<0.05$, one-way ANOVA). FW, fresh weight 
Silencing of OsPHR3 differentially affects the expression of $\mathrm{NO}_{3}{ }^{-}$and $\mathrm{NH}_{4}{ }^{+}$transporter and $\mathrm{NO}_{3}{ }^{-}$reductase genes under different $\mathrm{N}$ regimes

Since the mutation in OsPHR3 exerted significant influences on the concentrations of total $\mathrm{N}, \mathrm{NO}_{3}{ }^{-}$and $\mathrm{NH}_{4}{ }^{+}$ (Fig. 3), the influx rate and translocation of $\mathrm{NO}_{3}{ }^{-}$and $\mathrm{NH}_{4}{ }^{+}$(Fig. 4) and the concentration and remobilization of $\mathrm{NO}_{3}{ }^{-}$from OLB to YLB (Fig. 5), it raised a pertinent question about its likely influence on the relative expression of the genes implicated in sensing and signaling cascades governing $\mathrm{N}$ homeostasis. Several genes have been identified that play pivotal roles in $\mathrm{N}$ assimilation and use efficiency [2]. Among these genes, those encoding for transporters for $\mathrm{NO}_{3}^{-}$(OsNRTs) [29-33] and $\mathrm{NH}_{4}{ }^{+}$(OsAMTs) [34-36] have been functionally characterized. $\mathrm{NO}_{3}{ }^{-}$reductase genes (OsNia1 and OsNia2) play a role in converting $\mathrm{NO}_{3}{ }^{-}$to $\mathrm{NH}_{4}{ }^{+}$in roots, which related to $\mathrm{N}$ metabolism [2]. The expression pattern of the $\mathrm{NO}_{3}{ }^{-}$reductase genes are well known to be low during nitrate deficiency and high in nitrate-sufficiency [37]. Therefore, qRT-PCR was employed to determine the effects of the mutation in OsPHR3 on the relative expression levels of $\mathrm{NO}_{3}^{-}$(OsNRT1.1a, OsNRT2.3a and OsNRT2.4) and $\mathrm{NH}_{4}{ }^{+}$(OsAMT1.1, OsAMT1.2, and OsAMT1.3) transporter and $\mathrm{NO}_{3}{ }^{-}$reductase (OsNial and OsNia2) genes in the roots of the wild-type and the mutants (osphr3-1 and osphr3-2) grown hydroponically under $+\mathrm{N}$ and $-\mathrm{N}$ conditions (Fig. 6). The relative expression levels of these genes were comparable in the wild-type and the mutants under $+\mathrm{N}$ (OsNRT2.4 and OsAMT1.1), $-\mathrm{N}$ (OsAMT1.3) or both under $+\mathrm{N}$ and $-\mathrm{N}$ conditions (OsNRT2.3a and OsAMT1.2) $(+\mathrm{N}$ and $-\mathrm{N}$ indicate $2.5 \mathrm{mM}$ and $0.25 \mathrm{mM} \mathrm{N}$, respectively). On the contrary, the relative expression levels of OsNRT1.1a
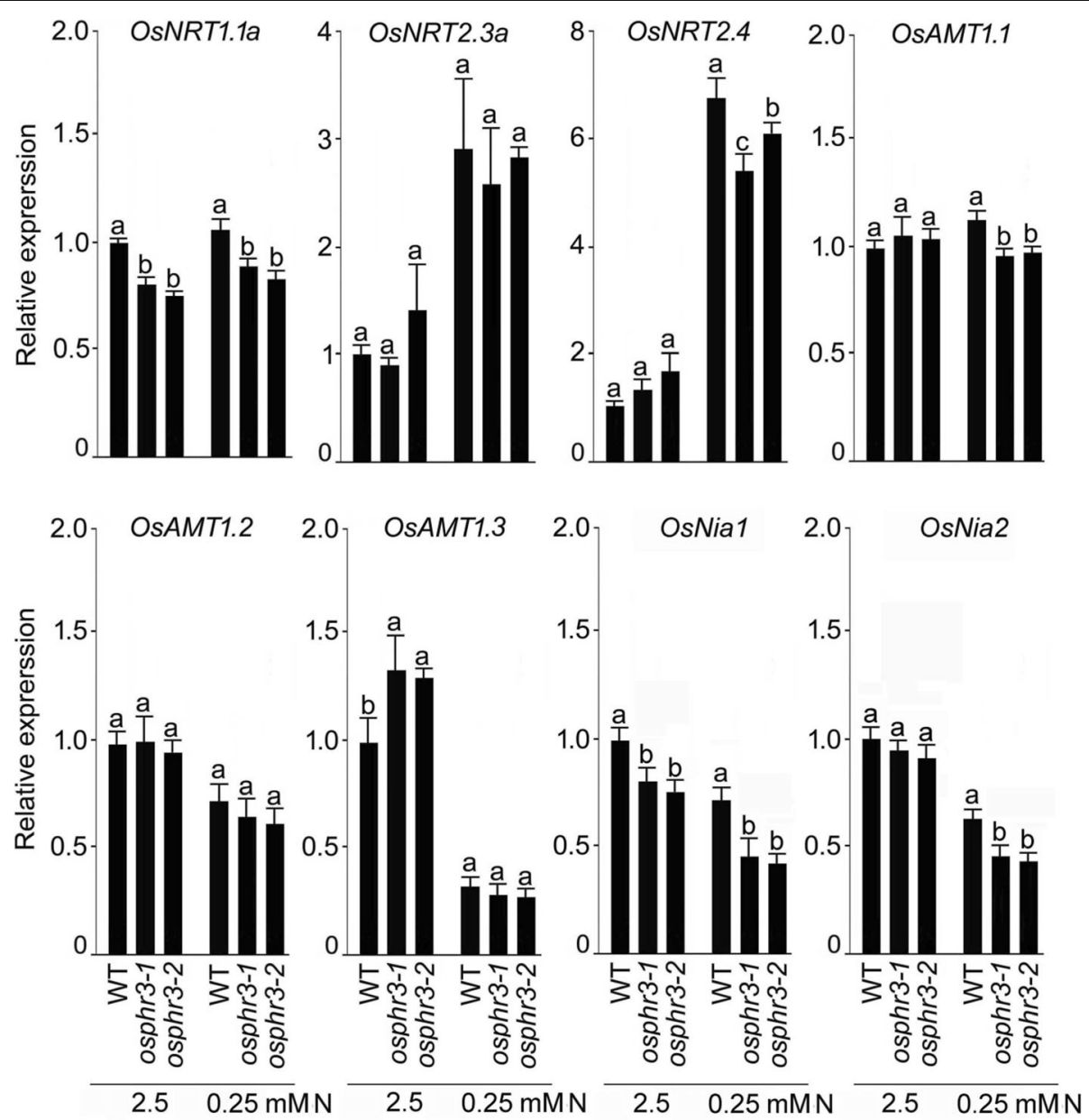

Fig. 6 Mutation in OsPHR3 affects the expression of $\mathrm{NO}_{3}{ }^{-}$and $\mathrm{NH}_{4}{ }^{+}$transporter and nitrate reductase genes. Seeds of the WT and mutants (osphr3-1 and 3-2) were grown hydroponically in IRRI solution for 2 weeks, deprived of $\mathrm{N}$ for $3 \mathrm{~d}$ and then transferred to $2.5 \mathrm{mM} \mathrm{N}$ and $0.25 \mathrm{mM} \mathrm{N}$ media for $1 \mathrm{~d}$. Roots were harvested and qRT-PCR was employed for determining the relative expression levels of genes encoding $\mathrm{NO}_{3}{ }^{-}$(OsNRT1.1 1 , OsNRT2.3a and OsNRT2.4), $\mathrm{NH}_{4}{ }^{+}$(OsAMT1.1, OsAMT1.2 and OsAMT1.3) transporters and nitrate reductase (OsNia1 and OsNia2). Actin was used as an internal control and +N WT values were normalized to 1. Values are means $\pm \operatorname{SE}(n=3)$ and different letters on the histograms indicate that the values differ significantly $(P<0.05$, one-way ANOVA) 
and OsNial under $+\mathrm{N}$ and $-\mathrm{N}$ condition, and those of OsNRT2.4, OsAMT1.1 and OsNia2 under -N condition were significantly attenuated in the mutants compared with the wild-type. The relative expression level of OsAMT1.3 under $+\mathrm{N}$ condition was significantly augmented compared with the wild-type. The results suggested differential regulatory influences of OsPHR3 on the relative expression levels of $\mathrm{NO}_{3}{ }^{-}$and $\mathrm{NH}_{4}{ }^{+}$transporter and $\mathrm{NO}_{3}{ }^{-}$reductase genes under different $\mathrm{N}$ regimes.

\section{OsPHR3 affects lateral root development under different $\mathrm{NO}_{3}{ }^{-}$regimes independent of pi availability}

Several studies have shown the prevalence of a cross-talk between sensing and signaling cascades governing homeostasis of $\mathrm{Pi}$ and $\mathrm{NO}_{3}{ }^{-}$in Arabidopsis [38-40] and rice [41]. To know whether the relative expression of OsPHR3 response to different $\mathrm{NO}_{3}{ }^{-}$regimes depending on Pi availability, the relative expression levels of OsPHR3 under $\mathrm{H} /$ $\mathrm{L} \mathrm{NO}_{3}{ }^{-}+\mathrm{P}$ and $\mathrm{H} / \mathrm{L} \mathrm{NO}_{3}{ }^{-}-\mathrm{P}$ conditions were detected (Fig. 7a). It was found that the relative expression levels of OsPHR3 were reduced significantly in $\mathrm{L} \mathrm{NO}_{3}{ }^{-}$shoot and $\mathrm{L} \mathrm{NO}_{3}{ }^{-}$root compared with $\mathrm{H} \mathrm{NO}_{3}{ }^{-}$seedling under both $+\mathrm{P}$ and $-\mathrm{P}$ conditions (Fig. 7a). The wild-type and the mutants (osphr3-1and osphr3-2) were grown hydroponically under various $\mathrm{NO}_{3}{ }^{-}$and $\mathrm{NH}_{4}{ }^{+}$regimes for $10 \mathrm{~d}$ (Fig. 7 and Additional file 5). To observe if there were any detectable changes in the lateral root initiation, their seminal roots (2-4 $\mathrm{cm}$ from the tip) were stained with methylthionine chloride (Fig. 7b, c and Additional file 5). The number of lateral root primordia was comparable between the wild-type and the mutants when grown under different $\mathrm{NH}_{4}{ }^{+}$regimes (Additional file 5), while it was significantly higher in the mutants both under $\mathrm{H} \mathrm{NO}_{3}^{-}(\sim 30-70 \%)$ and $\mathrm{L} \mathrm{NO}_{3}{ }^{-}(\sim 86-137 \%)$ compared with the wild-type (Fig. 7b, c). To further investigate, whether Pi availability exerts any influence on the developmental responses of the lateral roots under different $\mathrm{NO}_{3}{ }^{-}$regimes, the wild-type, and mutants (osphr3-1 and osphr3-2) were grown hydroponically under $+\mathrm{P} / \mathrm{H} \mathrm{NO}_{3}{ }^{-},-\mathrm{P} / \mathrm{H} \mathrm{NO}_{3}{ }^{-},+\mathrm{P} /$ $\mathrm{L} \mathrm{NO}_{3}{ }^{-}$and $-\mathrm{P} / \mathrm{L} \mathrm{NO}_{3}{ }^{-}$conditions (Fig. $7 \mathrm{~d}-\mathrm{f}$ ). Minor differences were observed in the lateral root phenotype of the wild-type and the mutants under all the 4 conditions tested (Fig. 7d). The average length of lateral roots of the mutants were significantly higher $(\sim 60-69 \%$ in $+\mathrm{P} / \mathrm{H}$ $\mathrm{NO}_{3}{ }^{-}, \sim 26-31 \%$ in $+\mathrm{P} / \mathrm{L} \mathrm{NO}_{3}{ }^{-}, \sim 42-47 \%$ in $+\mathrm{P} / \mathrm{H} \mathrm{NO}_{3}{ }^{-}$ and $\sim 21-25 \%$ in $-\mathrm{P} / \mathrm{L} \mathrm{NO}_{3}^{-}$) in the mutants compared with their corresponding wild-type (Fig. 7e). Although the density of lateral roots of the wild-type and the mutants were comparable under $+\mathrm{P} / \mathrm{H} \mathrm{NO}_{3}{ }^{-}$and $+\mathrm{P} / \mathrm{H} \mathrm{NO}_{3}{ }^{-}$, the values were significantly higher in the mutants compared with the wild-type under both $+\mathrm{P} / \mathrm{L} \mathrm{NO}_{3}{ }^{-}(\sim 40-47 \%)$ and $-\mathrm{P} / \mathrm{L} \mathrm{NO}_{3}^{-}(\sim 25-33 \%)$ (Fig. 7f). These results revealed that OsPHR3 exerts regulatory influences on the developmental responses of the lateral roots under different $\mathrm{NO}_{3}{ }^{-}$regimes independent of $\mathrm{Pi}$ availability. However, there were no significant differences in the average length of the lateral roots of the wild-type and the mutants grown under different $\mathrm{NH}_{4}{ }^{+}$regimes (Additional file 5).

\section{Silencing of OsPHR3 affects $\mathrm{N}$ homeostasis independent of pi availability}

Earlier studies have shown the prevalence of a cross-talk between the homeostasis of $\mathrm{N}$ and $\mathrm{Pi}$ in rice $[9,10]$. The $\mathrm{Pi}$ and total $\mathrm{P}$ concentration under different $\mathrm{N}$ conditions were not affected by the mutation of OsPHR3 in both shoot and root (Additional file 6). $\mathrm{T}$ o determine the effects of Pi availability on the total $\mathrm{N}$ and $\mathrm{NO}_{3}{ }^{-}$concentration, the wild-type and the mutants (osphr3-1and osphr3-2) were grown hydroponically under different $\mathrm{Pi}$ regimes for 2 weeks. Shoot and root were harvested and assayed for total $\mathrm{N}$ (Fig. 8a) and $\mathrm{NO}_{3}{ }^{-}$(Fig. 8b) concentrations. Consistent with the earlier studies $[9,10]$, Pi deficiency triggered significant reductions in the total $\mathrm{N}$ and $\mathrm{NO}_{3}{ }^{-}$concentration in the shoot and root of wild-type, osphr3-1 and osphr3-2 (Fig. 8a, b). Further, the mutation of OsPHR3 reduced the total $\mathrm{N}$ and $\mathrm{NO}_{3}{ }^{-}$concentration under both $+\mathrm{P}$ and $-\mathrm{P}$ conditions (Fig. 8a, b). The results suggested that the mutation in OsPHR3 does not affect the regulatory mechanism governing accumulation of $\mathrm{N}$ under different Pi regimes. Further, the relative expression levels of the $\mathrm{NO}_{3}^{-}$(OsNRT1.1a, OsNRT2.3a and OsNRT2.4) and $\mathrm{NH}_{4}^{+}$(OsAMT1.1, OsAMT1.2, and OSAMT1.3) transporter genes were assayed in the roots of the wild-type and the mutants (osphr3-1 and osphr3-2) grown hydroponically under $+\mathrm{P}$ and $-\mathrm{P}$ conditions for $3 \mathrm{~d}$ (Fig. 8c). Pi deprivation exerted variable influences on the relative expression levels of these genes in roots of the wild-type ranging from no significant effects on OsNRT2.3a and OsNRT2.4, induction of OsNRT1.1a and suppression of OsAMT1.1, OsAMT1.2, and OsAMT1.3. It is noteworthy that the variable effects of Pi deprivation on the relative expression levels of these genes in the mutants were comparable with the wild-type (Fig. 8c). The results suggested that the mutation in OsPHR3 affects the molecular traits governing $\mathrm{N}$ homeostasis independent of $\mathrm{Pi}$ availability.

\section{Discussion}

In higher plants, deficiencies of $\mathrm{Pi}$ and/or $\mathrm{N}$ trigger an array of adaptive morphophysiological responses and induction or suppression of several genes belonging to different functional categories [2, 6-8]. These genes are transcriptionally regulated by a host of TFs $[2,11]$. Among the TFs, the functional characterization of PHR1 in Arabidopsis [14-16, 21] and its ortholog OsPHR2 in rice [26] provided a framework of a central regulatory system governing transcriptional responses to $\mathrm{Pi}$ 

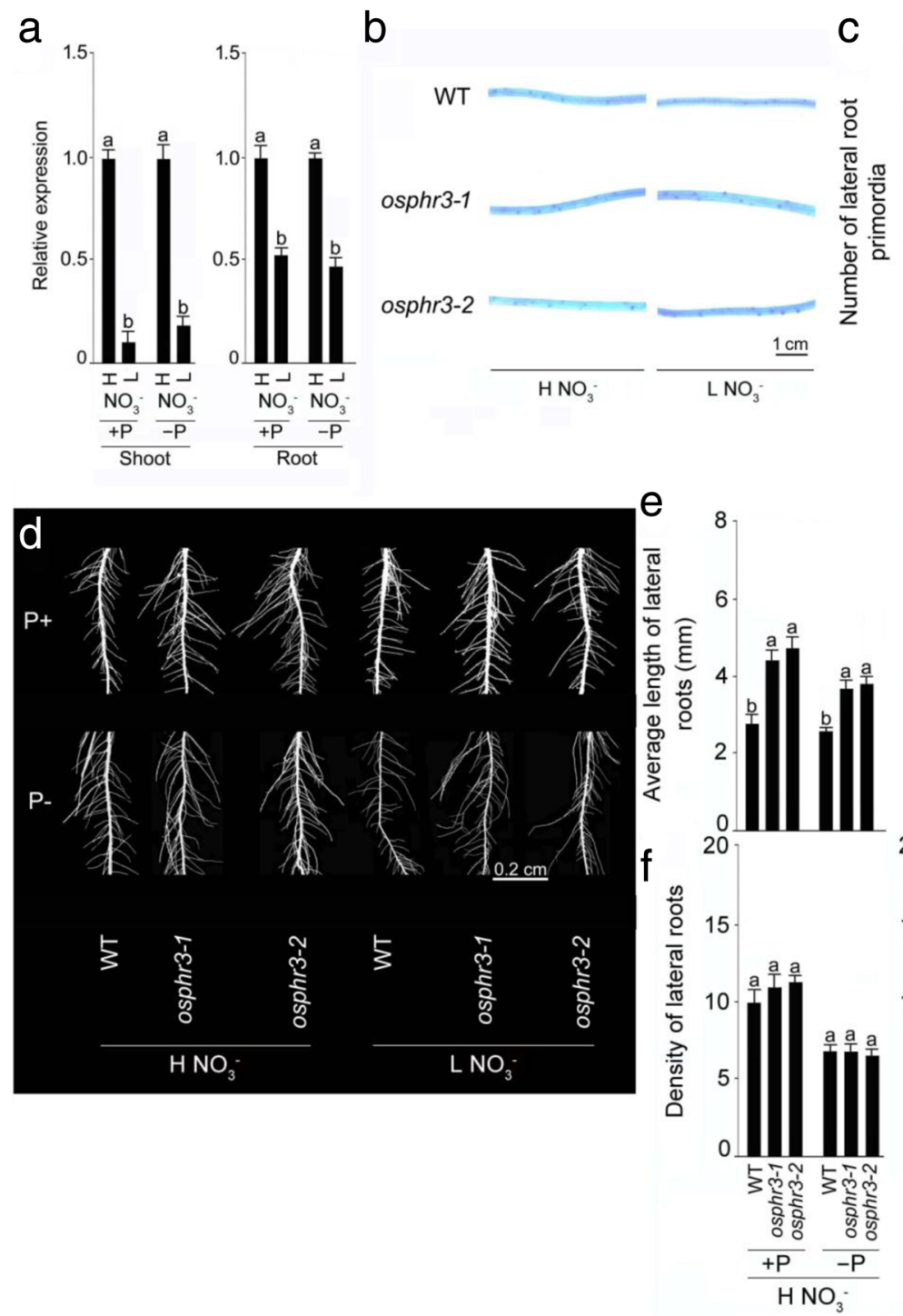

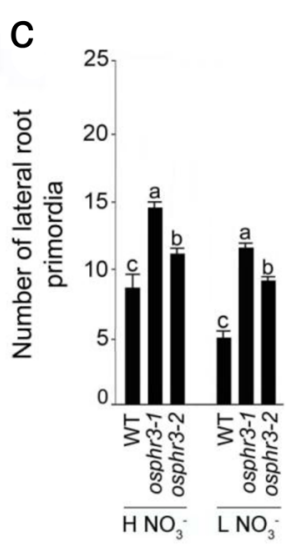

8

6

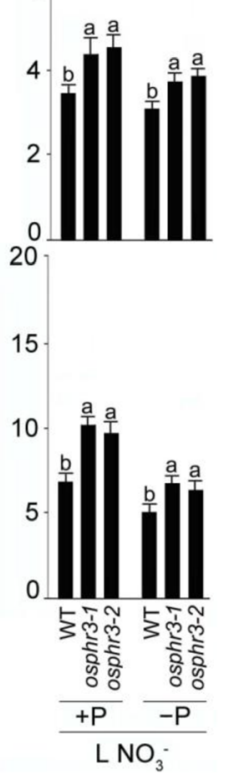

Fig. 7 Responses of OsPHR3 expression and lateral roots development in osphr3 under $\mathrm{H} / \mathrm{L} \mathrm{NO}_{3}{ }^{-}$are Pi-independent. Seeds of the WT and mutants (osphr3-1 and 3-2) were grown hydroponically in media comprising $\mathrm{HNO}_{3}^{-}+\mathrm{P}, \mathrm{HNO}_{3}^{-}-\mathrm{P}, \mathrm{L} \mathrm{NO}_{3}^{-}+\mathrm{P}$ and $\mathrm{LNO}_{3}^{-}-\mathrm{P}$ for 10 d. a The relative expression level of OsPHR3 under different $\mathrm{NO}_{3}{ }^{-}$and $\mathrm{Pi}$ conditions. $\mathbf{b}$ Phenotype of primordia in $2-4 \mathrm{~cm}$ region from the tip of seminal root. d Seedlings showing lateral roots phenotype. Data are presented for (c) number of lateral root primordia, (e) average length and (f) density of lateral roots in $2-4 \mathrm{~cm}$ region from the tip of seminal root. Values are means \pm SE $(n=10)$ and different letters on the histograms indicate that the values differ significantly $(P<0.05$, one-way ANOVA)

deficiency in taxonomically diverse plant species. OsPHR3 plays an important role in improving the tolerance towards Pi deficiency [27]. PHR1-related PHL1 in Arabidopsis [16] and the paralogs of OsPHR2 i.e., OsPHR1, 3 and 4 in rice $[27,28]$ play functionally redundant roles in the maintenance of Pi homeostasis. Several studies have also shown the prevalence of a cross-talk between sensing and signaling cascades governing homeostasis of $\mathrm{Pi}$ and $\mathrm{N}$ in Arabidopsis [38-40, 42], rice [9] and maize [43]. Therefore, in this study, we investigated the likely role of OsPHR3 in regulating the homeostasis of different forms of $\mathrm{N}$ under different Pi regimes.
Among different available $\mathrm{N}$ sources, $\mathrm{NO}_{3}{ }^{-}$and $\mathrm{NH}_{4}{ }^{+}$ are often present in natural and cropland soils at much higher concentrations compared with other sources [44]. Therefore, effects of different forms and concentrations of $\mathrm{N}$ on the relative expression levels of OsPHR3 in root and shoot was determined by employing qRT-PCR (Fig. 1). $\mathrm{L} \mathrm{NH}_{4}{ }^{+}$(in root), $\mathrm{L} \mathrm{NO}_{3}{ }^{-}$and $-\mathrm{N}$ (in shoot and root) triggered attenuation in the relative expression levels of OsPHR3. OsPHR3 was significantly induced during Pi deficiency $[27,28]$. Interestingly, the relative expression level of OsPHR3 under $\mathrm{L} \mathrm{NH}_{4}{ }^{+}$was comparable with $\mathrm{H} \mathrm{NH}_{4}{ }^{+}$in the shoot (Fig. 1a). This 

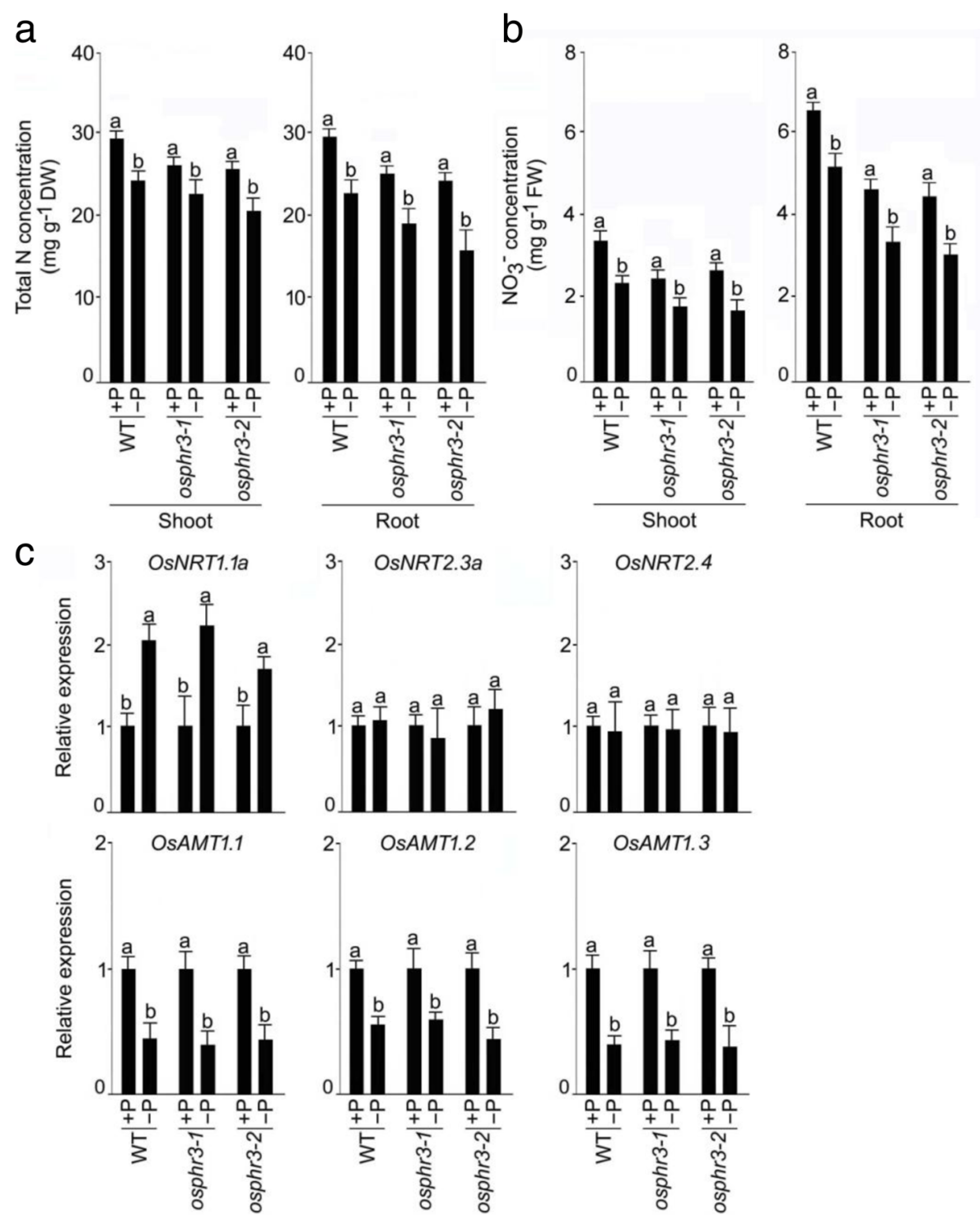

Fig. 8 Effects of total $\mathrm{N}_{1} \mathrm{NO}_{3}{ }^{-}$and expression of NRTs and AMTs are Pi-independent in osphr3. Seeds of the WT and mutants (osphr3-1 and 3-2) were grown hydroponically in IRRI solution for 2 weeks and then transferred to $+\mathrm{P}$ and $-\mathrm{P}$ for $(\mathbf{a}, \mathbf{b}) 2$ weeks and (c) $3 \mathrm{~d}$. Shoot and root were harvested for assaying the (a) total $\mathrm{N}$ and (b) $\mathrm{NO}_{3}{ }^{-}$concentration. c qRT-PCR was employed for determining the relative expression levels of genes encoding $\mathrm{NO}_{3}{ }^{-}$(OsNRT1.1a, OsNRT2.3a and OsNRT2.4) and $\mathrm{NH}_{4}{ }^{+}$(OsAMT1.1, OsAMT1.2 and OsAMT1.3) transporters in the root. Actin was used as an internal control and the values for $+P$ WT and $+P$ mutants were normalized to 1. Values of are means \pm SE $(n=5)$ and different letters on the histograms indicate that the values differ significantly $(P<0.05$, one-way ANOVA)

could be due to the fact that a large amount of $\mathrm{NH}_{4}{ }^{+}$ assimilates locally in the root [2].

Ty1-copia retrotransposon Tos17 is a potent tool for rice functional genomics [45]. Characterization of Tos17 insertion mutant osphr3 revealed the role of OsPHR3 in exerting a regulatory influence on Pi homeostasis in rice [27]. In this study, we used Tos17 insertion homozygous knock-out mutants osphr3-1, osphr3-2 and osphr3-3 (Additional file 2) for deciphering the effects of the mutation in OsPHR3 on various morphophysiological and molecular responses of rice during growth under different forms and concentrations of $\mathrm{N}$. In rice, post-embryonically developed adventitious and lateral roots constitute a bulk of the root system at maturity, while embryonically developed primary and seminal roots play important roles at the seedling stage [46, 47]. Adventitious roots facilitate nutrients and water uptake and gas exchange during flooding [48]. The root biomass $(+\mathrm{N}$ and $-\mathrm{N})$ and the average length of the adventitious roots under $\mathrm{H} \mathrm{NO}_{3}{ }^{-}, \mathrm{L} \mathrm{NO}_{3}{ }^{-}$and $\mathrm{L} \mathrm{NH}_{4}{ }^{+}$conditions were significantly lower in these mutants compared with the wild-type (Fig. 2a-d; Additional file 3). $\mathrm{NO}_{3}{ }^{-}$also 
acts as a signal and plays a dual role of stimulatory and inhibitory effects under mild and severe $\mathrm{N}$ deficiency, respectively on the total length of the lateral roots $[49,50]$. Here, the number of lateral root primordia (Fig. 7b, c) and density of lateral roots (irrespective of Pi regimes) (Fig. 7f) were significantly reduced in the wild-type under $\mathrm{L} \mathrm{NO}_{3}{ }^{-}$compared with $\mathrm{H} \mathrm{NO}_{3}{ }^{-}$. On the contrary, irrespective of $\mathrm{Pi}$ availability, average length of lateral roots was significantly higher in the wild-type under $\mathrm{L}$ $\mathrm{NO}_{3}{ }^{-}$compared with $\mathrm{H} \mathrm{NO}_{3}{ }^{-}$(Fig. 7e). Analysis of the mutants (osphr3-1 and osphr3-2) revealed negative regulatory influences of OsPHR3 on the developmental of the number of lateral root primordia $\left(\mathrm{H} \mathrm{NO}_{3}{ }^{-}\right.$and $\mathrm{L}$ $\mathrm{NO}_{3}{ }^{-}$) (Fig. 7b, c), and irrespective of Pi status, on an average length of lateral roots $\left(\mathrm{H} \mathrm{NO}_{3}{ }^{-}\right.$and $\left.\mathrm{L} \mathrm{NO}_{3}{ }^{-}\right)$ and density of lateral roots $\left(\mathrm{L} \mathrm{NO}_{3}{ }^{-}\right)$(Fig. $7 \mathrm{~d}-\mathrm{f}$ ). Auxin plays a pivotal role in the development of lateral roots [51-53] (De Smet et al., 2007, Laskowski et al., 2008, Mai et al., 2014). NRT1.1 has been shown to transport, in addition to $\mathrm{NO}_{3}{ }^{-}$, basipetal auxin and regulate development of the lateral root in response to the availability of external $\mathrm{L} \mathrm{NO}_{3}{ }^{-}$in Arabidopsis [54, 55]. The attenuated relative expression levels of OsNRT1.1a in $+\mathrm{N}$ and $-\mathrm{N}$ roots of the mutants (osphr3-1 and osphr3-1) compared with the wild-type (Fig. 6) suggested retarded auxin transport, which could have possibly triggered the elongation of the lateral roots in the mutants (Fig. 7e). However, the mutation in OsPHR3 did not exhibit any influence on the lateral root development when grown under different $\mathrm{NH}_{4}{ }^{+}$regimes (Additional file 5). This could be due to a more pronounced influence of $\mathrm{NO}_{3}{ }^{-}$ than $\mathrm{NH}_{4}{ }^{+}$on the developmental responses of the lateral roots $[56,57]$. The result suggested that OsPHR3 could positively influence the acquisition of $\mathrm{N}$ by exerting regulatory influences on the developmental responses of ontogenetically distinct different root traits. The adverse effects of the mutation in OsPHR3 were also evident at the grain-filling stage on the panicle development, per cent seed-set and grain yield (Fig. 2e-g). The results were in agreement with an earlier study, which reported higher grain yield in OsPHR3 overexpression lines compared with the wild-type [27].

Significant reductions in the concentrations of total N $\left(+\mathrm{N}\right.$ and $-\mathrm{N}$ shoot and root), $\mathrm{NO}_{3}{ }^{-}(+\mathrm{N}$ shoot, $+\mathrm{N}$ and $-\mathrm{N}$ root) and $\mathrm{NH}_{4}{ }^{+}$(-N root) in osph3-1 and osphr3-2 mutants compared with the wild-type suggested positive regulatory influence of OsPHR3 on different forms and concentrations of $\mathrm{N}$ in a tissue-specific manner (Fig. 3a-c). It was interesting to note that the concentrations of total $\mathrm{N}$ and $\mathrm{NH}_{4}{ }^{+}$in the shoot were comparable in the mutants and the wild-type, while all forms of $\mathrm{N}$ showed attenuation in $-\mathrm{N}$ roots (Fig. 3a-c). It is not surprising because roots are involved in sensing and acquisition of $\mathrm{N}$ from the soil in the form of $\mathrm{NO}_{3}{ }^{-}$and $\mathrm{NH}_{4}{ }^{+}$[49]. The differential effects of the mutation in OsPHR3 were also evident in the concentration of total $\mathrm{N}$ in different tissues at the reproductive stage ranging from significant reduction in 6th leaf blade, increases in 1st leaf blade and seed and remained unaffected in other tissues (3rd leaf blade, culm, leaf sheath and panicle) compared with the wild-type (Additional file 4). $\mathrm{NO}_{3}{ }^{-}$and $\mathrm{NH}_{4}{ }^{+}$are predominant inorganic forms of $\mathrm{N}$ in aerated soils and anaerobic environments, respectively and their mixture is often beneficial to plants for augmenting their $\mathrm{N}$ content and consequently growth and development [58]. Although $\mathrm{NH}_{4}{ }^{+}$is often preferred over $\mathrm{NO}_{3}{ }^{-}$as the $\mathrm{N}$ source due to the lower energy requirement by the former for assimilation by roots [59], acquisition of $\mathrm{NH}_{4}{ }^{+}$and its subsequent translocation is significantly enhanced by $\mathrm{NO}_{3}{ }^{-}$availability but the former strongly suppresses influx of the latter $[46,60]$. Therefore, interactions between $\mathrm{NO}_{3}{ }^{-}$and $\mathrm{NH}_{4}{ }^{+}$are critical for optimal utilization of $\mathrm{N}$ by the plants. Mutation in OsPHR3 resulted in the attenuated influx rates of both ${ }^{15} \mathrm{~N}-\mathrm{NO}_{3}{ }^{-}$ and ${ }^{15} \mathrm{~N}^{-\mathrm{NH}_{4}}{ }^{+}$under $-\mathrm{N}$ condition (Fig. 4a, c). The low level of $\mathrm{N}$ induced the development of primary root [61]. However, the mutation of OsPHR3 significantly reduced the primary root development and root biomass (Fig. 2). This could be one of the reasons for the lower $\mathrm{N}$ uptake rate in the mutants compared with the wild-type. The ratio (translocation) of ${ }^{15} \mathrm{NO}_{3}{ }^{-}$in $+\mathrm{N}$ root was also significantly reduced in the mutants compared with the wild-type (Fig. 4b). The results provided some explanation towards observed reductions in the concentrations of total $\mathrm{N}, \mathrm{NO}_{3}{ }^{-}$and $\mathrm{NH}_{4}{ }^{+}$in $-\mathrm{N}$ roots of the mutants compared with the wild-type (Fig. 3a-c). On the contrary, OsPHR3 negatively regulated mobilization of $\mathrm{NO}_{3}{ }^{-}$from OLB to YLB under different $\mathrm{NO}_{3}{ }^{-}$regimes (Fig. 5a) and redistribution of ${ }^{15} \mathrm{NO}_{3}{ }^{-}$ (Fig. 5b). The data thus provided evidence towards the key role of OsPHR3 in regulating the homeostasis of $\mathrm{N}$, $\mathrm{NO}_{3}{ }^{-}$and $\mathrm{NH}_{4}{ }^{+}$under different $\mathrm{N}$ regimes in a tissue-specific manner.

This raised a question whether genes encoding for transporters for $\mathrm{NO}_{3}{ }^{-}$(OsNRTS) [29-33, 62, 63] and $\mathrm{NH}_{4}{ }^{+}$(OsAMTs) [34-36] are transcriptionally regulated by OsPHR3. OsNRT1.1a encodes a low-affinity $\mathrm{NO}_{3}{ }^{-}$ transporter and plays a role in the accumulation of $\mathrm{N}$ [63]. Whereas, OsNRT2.4 is largely expressed in the base of the lateral root primordia, leaves, hull and in the vascular tissue of the anther and its expression is relatively much higher in the roots supplied with $\mathrm{NO}_{3}{ }^{-}$compared with $\mathrm{NH}_{4}^{+}$solution [29]. It played a role in $\mathrm{NO}_{3}{ }^{-}$regulated root growth and $\mathrm{NO}_{3}{ }^{-}$distribution [62]. Transgenic rice overexpressing high-affinity $\mathrm{NH}_{4}{ }^{+}$transporter OsAMT1;1 has higher $\mathrm{NH}_{4}^{+}$permeability and exhibits better growth and higher yield under optimal and suboptimal $\mathrm{NH}_{4}{ }^{+}$conditions [35]. OsAMT1.3 also encodes a 
high-affinity $\mathrm{NH}_{4}{ }^{+}$transporter, which is expressed predominantly in $-\mathrm{N}$ roots [36]. Here, the mutation in OsPHR3 caused significant reductions in the relative expression levels of OsNRT1.1a ( $+\mathrm{N}$ and $-\mathrm{N}$ conditions), OsNRT2.4 and OsAMT1.1 (-N condition) and but augmentation in the relative expression levels of OsAMT1.3 $(+\mathrm{N}$ condition) (Fig. 6). These results suggested that the decrease of $\mathrm{N}$ uptake and accumulation may be due to the down-regulation of the ammonium and nitrate transporter genes in the OsPHR3 mutants. Furthermore, $\mathrm{NO}_{3}{ }^{-}$is converted to $\mathrm{NH}_{4}{ }^{+}$by $\mathrm{NO}_{3}{ }^{-}$reductase (NR) and nitrite reductase (NiR), and the $\mathrm{NH}_{4}{ }^{+}$derived from $\mathrm{NO}_{3}{ }^{-}$and/or directly acquired by the root is further assimilated into amino acids in the shoot [2]. In our study, the $\mathrm{NO}_{3}{ }^{-}$reductase genes (OsNia1 and OsNia2) were reduced in $+\mathrm{N}$ root (OsNia1) and $-\mathrm{N}$ root (OsNia1 and OsNia2) in the mutants (Fig. 6). It maybe a reason which cause the strong reduction of $\mathrm{NH}_{4}{ }^{+}$concentration in root of mutants under $-\mathrm{N}$ condition (Fig. 3c). These results of relative expression levels preliminarily explain the reduction of total $\mathrm{N}, \mathrm{NO}_{3}{ }^{-}$and $\mathrm{NH}_{4}{ }^{+}$concentration, influx rate and translocation ratio in the mutants (Figs. 3 and 4). This study thus suggested a pivotal role of OsPHR3 in regulating the expression of a subset of genes, which are involved in the maintenance of the homeostasis of $\mathrm{NO}_{3}{ }^{-}, \mathrm{NH}_{4}{ }^{+}$and $\mathrm{N}$. All the $\mathrm{N}$ treatments were carried out as described [31, 64] with slight modifications. The 2-week old wild-type and the mutants (grown hydroponically in IRRI solution) to $\mathrm{N}$ starvation for $3 \mathrm{~d}$ was to ensure the consumption of $\mathrm{N}$ before subjecting them to different treatments. This is a conventional practice that has been followed in our earlier studies as well [31, 64]. Among the NRT genes in rice, the expression of OsNRT2.4 was significantly induced by both low $\mathrm{N}$ and $\mathrm{P}$ [65]. The cis-element analysis by PLACE (https://sogo.dna.affrc.go.jp/cgibin/ sogo.cgi?lang $=$ en $\& p j=640 \&$ action $=$ page $\&$ page $=$ newplace $)$ showed that there were several Pi related cis-elments on the promoter of OsNRT2.4, such as W-box. However, there was no P1BS, which is the PHR1-specific binding sequence [14]. It suggested that OsPHR3 may regulate the $N R T$ genes in an indirect manner. The more detailed mechanism need further verification.

Earlier studies have also shown the prevalence of an antagonistic cross-talk between signaling pathways of $\mathrm{N}$ and $\mathrm{Pi}$ in rice [9] and Arabidopsis [39, 40, 42]. For instance, GARP TF HRS1 suppresses primary root growth during Pi deficiency only when $\mathrm{NO}_{3}{ }^{-}$is present [40], and lower $\mathrm{NO}_{3}{ }^{-}$and higher $\mathrm{Pi}$ concentrations promote flowering [39]. This led us to investigate whether the availability of $\mathrm{Pi}$ would exert any influence on the regulation of OsPHR3 in various responses to different $\mathrm{NO}_{3}{ }^{-}$or $\mathrm{N}$ regimes. $\mathrm{NO}_{3}{ }^{-}$deficiency triggered attenuation in the relative expression of OsPHR3 in shoot and root under both $+\mathrm{P}$ and -P conditions (Fig. 7a). This provided evidence towards
$\mathrm{NO}_{3}{ }^{-}$deficiency-mediated suppression of OsPHR3 in the root independent of Pi availability. In terms of the development of lateral roots, it was observed that the responses of elongation and density of lateral roots in mutants to different $\mathrm{NO}_{3}{ }^{-}$regimes were independent on $\mathrm{Pi}$ availability (Fig. 7d-f). Although Pi deficiency triggered a significant reduction in the concentration of total $\mathrm{N}$ and $\mathrm{NO}_{3}{ }^{-}$in the shoot and root of the wild-type, the mutation in OsPHR3 did not alter the trend (Fig. 8a, b). These results provided empirical evidences toward the regulatory influence of OsPHR3 on the responses to $\mathrm{NO}_{3}^{-}$treatments and the concentration of total $\mathrm{N}$ and $\mathrm{NO}_{3}{ }^{-}$independent of Pi status. Although the effects of Pi deficiency on the relative expression levels of these genes were differential ranging from no influence (OsNRT2.3a and OsNRT2.4), inhibitory (OsAMT1;1, OsAMT1;2 and OsAMT1;3) and stimulatory (OsNRT1.1a) in the wild-type, the mutants (osphr3-1 and osphr3-2) revealed a similar trend (Fig. 8b). However, the $\mathrm{Pi}$ and total $\mathrm{P}$ concentration were not affected by the mutation of OsPHR3 under both $+\mathrm{N}$ and $-\mathrm{N}$ conditions (Additional file 6). The results were in agreement with an earlier study (Guo et al. 2015). This could possibly be due to the redundant role of OsPHR3 with other PHR1 family members $(P H R 1 / 2 / 4)$ in regulating Pi homeostasis under different $\mathrm{N}$ regimes $[27,28]$. The results provided evidence towards the regulatory influence of OsPHR3 on these genes under different $\mathrm{N}$ regimes irrespective of Pi regimes.

\section{Conclusion}

This study presented that OsPHR3 is responsive to different forms of $\mathrm{N}$ irrespective of Pi regimes. The silencing of this gene triggered wide-spectrum effects on phenotypes during vegetative and reproductive growth phases. The analysis of total $\mathrm{N}, \mathrm{NO}_{3}{ }^{-}$and $\mathrm{NH}_{4}{ }^{+}$concentrations, influx rates, translocation and distribution ratio of ${ }^{15} \mathrm{~N}$, and relative expression levels of $\mathrm{N}$ transport and metabolism related genes suggested that silencing of OsPHR3 regulated $\mathrm{N}$ homeostasis in tissue-specific manner. Further an insight into the likely roles of OsPHR3 in regulating the lateral root development under different $\mathrm{NO}_{3}{ }^{-}$regimes and $\mathrm{N}$ homeostasis independent on $\mathrm{Pi}$ availability were gained. These results from the study explain that availability of Pi did not exert any notable effects on OsPHR3-mediated regulatory influence on $\mathrm{N}$ homeostasis under different $\mathrm{N}$ variants and the lateral root development under different $\mathrm{NO}_{3}{ }^{-}$treatments. It provide a basis for further detailed characterization of the cross-talk between $\mathrm{N}$ and $\mathrm{P}$.

\section{Methods}

Plant materials and growth conditions

Wild-type rice (Oryza sativa L. ssp. japonica cv. Nipponbare) was used in the present study. The mutants osphr3-1 (RTIM NE3007), osphr3-2 (RTIM NE3709) 
and osphr3-3 (RTIM NE3735) in Nipponbare background were obtained from the rice Tos 17 insertion mutant database (https://tos.nias.affrc.go.jp). Homozygous mutants were identified by using a set of primers (P1-P5) in two-round semi-quantitative RT-PCR and lack of OsPHR3 transcripts validated their fidelity (Additional files 2 and 7). Seeds of the wild-type and the mutants were grown hydroponically in IRRI solution comprising $\mathrm{NH}_{4} \mathrm{NO}_{3}(1.25 \mathrm{mM}), \mathrm{CaCl}_{2}(1 \mathrm{mM}), \mathrm{MgSO}_{4}$ (1 mM), $\mathrm{Na}_{2} \mathrm{SiO}_{3}(0.5 \mathrm{mM}), \mathrm{K}_{2} \mathrm{SO}_{4}(0.35 \mathrm{mM}), \mathrm{KH}_{2} \mathrm{PO}_{4}$ $(0.3 \mathrm{mM})$, EDTA-Fe $(20 \mu \mathrm{M}), \mathrm{H}_{3} \mathrm{BO}_{3}(20 \mu \mathrm{M}), \mathrm{MnCl}_{2}$ $(9 \mu \mathrm{M}), \mathrm{ZnSO}_{4}(0.77 \mu \mathrm{M}),\left(\mathrm{NH}_{4}\right)_{6} \mathrm{Mo}_{7} \mathrm{O}_{24}(0.39 \mu \mathrm{M})$ and $\mathrm{CuSO}_{4}(0.32 \mu \mathrm{M})$ with $\mathrm{pH}$ adjusted to 5.5. Seedlings were then transferred to nutrient solution containing different form and concentration of $\mathrm{N}:+\mathrm{N}(2.5 \mathrm{mM}),-\mathrm{N}$ (0 mM), high $\mathrm{NH}_{4}{ }^{+}\left(\mathrm{H} \mathrm{NH}_{4}{ }^{+}, 5 \mathrm{mM}\right)$, low $\mathrm{NH}_{4}{ }^{+}\left(\mathrm{L} \mathrm{NH}_{4}{ }^{+}\right.$, $0.25 \mathrm{mM})$, high $\mathrm{NO}_{3}{ }^{-}\left(\mathrm{H} \mathrm{NO}_{3}{ }^{-}, 5 \mathrm{mM}\right)$ and low $\mathrm{NO}_{3}{ }^{-}$( $\mathrm{L}$ $\left.\mathrm{NO}_{3}{ }^{-}, 0.25 \mathrm{mM}\right)$. These hydroponic media were maintained either under $+\mathrm{P}(\mathrm{Pi}, 200 \mu \mathrm{M})$ or $-\mathrm{P}(\mathrm{Pi}, 0 \mu \mathrm{M})$ condition. To inhibit nitrification, hydroponic medium containing different concentration of $\mathrm{NH}_{4}{ }^{+}$was supplemented with $7 \mu \mathrm{M}$ of dicyandiamide $\left(\mathrm{C}_{2} \mathrm{H}_{4} \mathrm{~N}_{4}\right)$. Plants were grown under controlled conditions $\left(16 \mathrm{~h}\right.$ light, $30{ }^{\circ} \mathrm{C} / 8 \mathrm{~h}$ dark, $22{ }^{\circ} \mathrm{C}$ cycle and $\sim 70 \%$ relative humidity).

\section{qRT-PCR analysis}

Total RNA $(\sim 1 \mu \mathrm{g})$ was extracted from the plant tissue by using Trizol reagent (Invitrogen) and treated with RNase-free DNase (Thermoscientific). First-strand cDNA was synthesized using an oligo (dT) 18 primer and reverse transcribed using Superscript $\mathrm{II}^{\mathrm{m}}$ Reverse Transcriptase (Invitrogen). OsActin (accession number AB047313) was used as an internal control and qRT-PCR analysis was performed by using SYBR Premix Ex Taq $^{\text {Ti }}$ II (TaKaRa) in StepOnePlus ${ }^{\text {Ti }}$ Real-Time PCR System (Applied Biosystems). Relative expression levels of genes were computed by $2^{-\Delta \Delta C}$ method of relative quantification [66]. The gene-specific primers used are listed in Additional file 8.

\section{Quantification of total $\mathrm{N}, \mathrm{NO}_{3}{ }^{-}$and $\mathrm{NH}_{4}{ }^{+}$}

Different tissues were harvested and washed with $\mathrm{CaSO}_{4}$ $(0.1 \mathrm{mM})$ for $1 \mathrm{~min}$. Concentration of total $\mathrm{N}$ was determined by Kjeldahl method as described [67], while those of $\mathrm{NO}_{3}^{-}$and $\mathrm{NH}_{4}{ }^{+}$by using a continuous-flow auto-analyzer (AutoAnalyzer 3 ).

\section{Assay for the influx and distribution of $\mathrm{NO}_{3}{ }^{-}$and $\mathrm{NH}_{4}{ }^{+}$} Seedlings (3-d-old) of the wild-type and the mutants (osphr3-1and osphr3-2) were grown hydroponically in the IRRI nutrient solution for 2 weeks and then deprived of $\mathrm{N}$ for $3 \mathrm{~d}$. Plants were rinsed in $\mathrm{CaSO}_{4}(0.1 \mathrm{mM})$ for $1 \mathrm{~min}$ and then transferred to the IRRI nutrient solution containing either $0.25 \mathrm{mM}$ or $2.5 \mathrm{mM}^{15} \mathrm{NO}_{3}{ }^{-}$(atom \% $\left.{ }^{15} \mathrm{~N}:{ }^{15} \mathrm{NO}_{3}^{-}, 60 \%\right)$ and $0.25 \mathrm{mM}$ or $2.5 \mathrm{mM}^{15} \mathrm{NH}_{4}^{+}$ (atom $\%{ }^{15} \mathrm{~N}$ : ${ }^{15} \mathrm{NH}_{4}{ }^{+}, 60 \%$ ) for $10 \mathrm{~min}$ and $24 \mathrm{~h}$ for their influx and distribution (shoot/root), respectively. In addition, to determine the redistribution of $\mathrm{NO}_{3}{ }^{-}$from $\mathrm{N}$-starved old to the young leaf, wild-type and the mutants were grown to the five-leaf stage. $\mathrm{NO}_{3}{ }^{-}$concentration of the second leaf (old) and fourth leaf (young) of the wild-type and the mutants were analyzed. Then, the oldest leaf blade of each plant was wiped gently with a sponge and incubated in solution containing $5 \mathrm{mM} \mathrm{Ca}$ $\left({ }^{15} \mathrm{NO}_{3}\right)_{2}$ for $5 \mathrm{~h}$. After the treatment, the youngest leaf blade (first) from the top was sampled after $24 \mathrm{~h}$ for determining ${ }^{15} \mathrm{~N}$ distribution. Plants were finally rinsed in $\mathrm{CaSO}_{4}(0.1 \mathrm{mM})$ for $1 \mathrm{~min}$. Root and shoot were separated and frozen in liquid nitrogen. Tissues were ground to a fine powder, dried to a constant weight at $70{ }^{\circ} \mathrm{C}$ and $\sim 10 \mathrm{mg}$ dried tissue was analyzed using Isotope-ratio mass spectrometer (Thermo Fisher Scientific).

\section{Statistical analysis}

Data were analyzed by ANOVA using SPSS 20 program (www.spss.com). Duncan's multiple range test at $P<0.05$ was carried out for all the experiments to determine the significance between the control and treatments.

\section{Additional files}

Additional file 1: Comparative identity matrix and domain structure of

Additional file 2: Isolation and validation of OsPHR3 mutants. (PDF $155 \mathrm{~kb}$ ) Additional file 3: Mutation in OsPHR3 affects adventitious root length. (PDF $121 \mathrm{~kb}$ )

Additional file 4: Mutation in OsPHR3 differentially affects total $N$ concentration in different tissues. (PDF $129 \mathrm{~kb}$ )

Additional file 5: Mutation in OSPHR3 does not affect the lateral root development under different $\mathrm{NH}_{4}^{+}$regimes. (PDF $154 \mathrm{~kb}$ )

Additional file 6: Mutation in OsPHR3 has no effect on Pi and total P concentrations under different $\mathrm{N}$ regimes. (PDF $161 \mathrm{~kb}$ )

Additional file 7: Primers used for osphr3 mutant identification. (DOCX $12 \mathrm{~kb}$ ) Additional file 8: Gene-specific primers used for qRT-PCR. (DOCX 15 kb)

\section{Abbreviations}

MYB-CC: MYB coiled-coil; MYB-HTH: MYB helix-turn-helix; N: Nitrogen; $\mathrm{NH}_{4}{ }^{+}$: Ammonium; NiR: Nitrite reductase; $\mathrm{NO}_{3}{ }^{-}$: Nitrate; NR: Nitrate reductase; P1BS: PHR1-specific binding sequence; phl1: phr1-like1; PHR: PHOSPHATE STARVATION RESPONSE 1; Pi: Phosphate; PSR: Phosphate-starvation responsive; PSR1: PHOSPHATE STARVATION RESPONSE 1; PT: Phosphate transporter; TF: Transcription factor

\section{Acknowledgements}

We thank S.Vishwanathan (India) for going through the manuscript critically. Mutant lines obtained from the rice Tos17 insertion mutant database (https://tos.nias.affrc.go.jp/).

\section{Funding}

The analysis of OsPHR3 function in N homeostasis in this work was supported by Chinese National Natural Science Foundation (31672226) and The National Key Research and Development Program of China (2016yfd0100700). The phenotype analysis was supported by National 
Program on R\&D of Transgenic Plants (2016ZX08009-003-005). The obtained of mutants was supported by the Jiangsu Provincial Natural Science Foundation (BK20141367). The data analysis was supported by Innovative Research Team Development Plan of the Ministry of Education (IRT1256) and 111 Project (number 12009).

\section{Availability of data and materials}

All the data supporting the present findings is contained within the manuscript.

\section{Authors' contributions}

YS participated in planning and conducting the experiments, did bioinformatics analysis and helped in writing the manuscript.WL and LL carried out some experiments. AJ participated in analysis of the data, and helped in writing the manuscript. $\mathrm{HA}, \mathrm{XL}, \mathrm{BF}, \mathrm{LZ}$ and $\mathrm{ZZ}$ participated in carrying out different experiments. GX participated in planning the study. SS conceived the study, participated in planning and analysis of the data, and helped in writing the manuscript. All authors read and approved the final manuscript.

\section{Ethics approval and consent to participate}

Not applicable.

\section{Consent for publication}

Not applicable.

\section{Competing interests}

The authors declare that they have no competing interests.

\section{Publisher's Note}

Springer Nature remains neutral with regard to jurisdictional claims in published maps and institutional affiliations.

\section{Author details \\ ${ }^{1}$ State Key Laboratory of Crop Genetics and Germplasm Enhancement, Key Laboratory of Plant Nutrition and Fertilization in Low-Middle Reaches of the Yangtze River, Ministry of Agriculture, Nanjing Agricultural University, Nanjing 210095, China. ${ }^{2}$ Institute of Eco-Environment and Plant Protection, Shanghai Academy of Agricultural Sciences, Shanghai 201403, China. ${ }^{3}$ Amity Institute of Biotechnology, Amity University Rajasthan, Kant Kalwar, NH-11C, Jaipur 303002, India.}

Received: 28 February 2018 Accepted: 3 October 2018 Published online: 17 October 2018

\section{References}

1. Marschner H. Mineral nutrition of higher plants. London: Academic press; 1995

2. Xu G, Fan X, Miller AJ. Plant nitrogen assimilation and use efficiency. Annu Rev Plant Biol. 2012;63:153-82.

3. Savci S. Investigation of effect of chemical fertilizers on environment. International Conference on Environmental Science \& Development; 2012. p. 287-92.

4. Schroeder Jl, Delhaize E, Frommer WB, Guerinot ML, Harrison MJ, HerreraEstrella L. Using membrane transporters to improve crops for sustainable food production. Nature. 2013;497:60-6.

5. Yang W, Yoon J, Choi H, Fan Y, Chen R, An G. Transcriptome analysis of nitrogen-starvation-responsive genes in rice. BMC Plant Biol. 2015;15:31.

6. López-Arredondo DL, Leyva-González MA, González-Morales SI, López-Bucio J, Herrera-Estrella L. Phosphate nutrition: improving low-phosphate tolerance in crops. Annu Rev Plant Biol. 2014;65:23.1-23.29.

7. Wu P, Shou H, Xu G, Lian X. Improvement of phosphorus efficiency in rice on the basis of understanding phosphate signaling and homeostasis. Curr Opin Plant Biol. 2013;16:205-12.

8. Chiou T-J, Lin SI. Signaling network in sensing phosphate availability in plants. Annu Rev Plant Biol. 2011;62:185-206.

9. Cai H, Xie W, Lian X. Comparative analysis of differentially expressed genes in rice under nitrogen and phosphorus starvation stress conditions. Plant Mol Biol Rep. 2013;31:60-173.

10. Wang H, Sun R, Cao Y, Pei W, Sun Y, Zhou H, Wu X, Zhang F, Luo L, Xu G, et al. OsSIZ1, a SUMO E3 ligase gene, is involved in the regulation of the responses to phosphate and nitrogen in rice. Plant Cell Physiol. 2015;56: 2381-95.
11. Jain A, Nagarajan VK, Raghothama KG. Transcriptional regulation of phosphate acquisition by higher plants. Cell Mol Life Sci. 2012;69:3207-24.

12. Franco-Zorrilla JM, López-Vidriero I, Carrasco JL, Godoy M, Verab P, Solano R. DNA-binding specificities of plant transcription factors and their potential to define target genes. Proc Natl Acad Sci U S A. 2014;111:2367-72.

13. Wykoff DD, Grossman AR, Weeks DP, Usuda H, Shimogawara K. Psr1, a nuclear localized protein that regulates phosphorus metabolism in Chlamydomonas. Proc Natl Acad Sci U S A. 1999;96:15336-41.

14. Rubio V, Linhares F, Solano R, Martin AC, Iglesias J, Leyva A, Paz-Ares J. A conserved MYB transcription factor involved in phosphate starvation signaling both in vascular plants and in unicellular algae. Genes Dev. 2001;15:2122-33.

15. Bari R, Pant BD, Stitt M, Scheible WR. PHO2, microRNA399, and PHR1 define a phosphate-signaling pathway in plants. Plant Physiol. 2006;141:988-99.

16. Bustos R, Castrillo G, Linhares F, Puga Ml, Rubio V, Pérez J, Solano R, Leyva A, Paz-Ares J. A central regulatory system largely controls transcriptional activation and repression responses to phosphate starvation in Arabidopsis. PLoS Genet. 2010;6:e1001102.

17. Nilsson L, Lundmark M, Jensen PE, Nielsen TH. The Arabidopsis transcription factor PHR1 is essential for adaptation to high light and retaining functional photosynthesis during phosphate starvation. Plant Physiol. 2012;144:35-47.

18. Sobkowiak L, Bielewicz D, Malecka EM, Jakobsen I, Albrechtsen M, Szweykowska-Kulinska Z, Pacak A. The role of the P1BS element containing promoter-driven genes in pi transport and homeostasis in plants. Front Plant Sci. 2012;3:58.

19. Pant BD, Burgos A, Pant P, Cuadros-Inostroza A, Willmitzer L, Scheible W-R. The transcription factor PHR1 regulates lipid remodeling and triacylglycerol accumulation in Arabidopsis thaliana during phosphorus starvation. J Exp Bot. 2015a;66:1907-18.

20. Pant BD, Pant P, Erban A, Huhman D, Kopka J, Scheible W-R. Identification of primary and secondary metabolites with phosphorus status-dependent abundance in Arabidopsis, and of the transcription factor PHR1 as a major regulator of metabolic changes during phosphorus limitation. Plant Cell Environ. 2015b;38:172-87.

21. Sun L, Song L, Zhang Y, Zheng Z, Liu D. Arabidopsis PHL2 and PHR1 act redundantly as the key components of the central regulatory system controlling transcriptional responses to phosphate starvation. Plant Physiol. 2016;170:499-514.

22. Bournier M, Tissot N, Mari S, Boucherez J, Lacombe E, Briat J-F, Gaymard F. Arabidopsis ferritin 1 (AtFer1) gene regulation by the phosphate starvation response 1 (AtPHR1) transcription factor reveals a direct molecular link between iron and phosphate homeostasis. J Biol Chem. 2013;288:22670-80.

23. Palmer $\mathrm{CM}$, Guerinot ML. Facing the challenges of $\mathrm{Cu}, \mathrm{Fe}$ and $\mathrm{Zn}$ homeostasis in plants. Nat Chem Biol. 2009;5:333-40.

24. Rouached $H$, Secco D, Arpat B, Poirier $Y$. The transcription factor PHR1 plays a key role in the regulation of sulfate shoot-to-root flux upon phosphate starvation in Arabidopsis. BMC Plant Biol. 2011;11:19.

25. Khan GA, Bouraine S, Wege S, Li Y, de Carbonnel M, Berthomieu P, Poirier Y, Rouached $\mathrm{H}$. Coordination between zinc and phosphate homeostasis involves the transcription factor PHR1, the phosphate exporter PHO1, and its homologue PHO1;H3 in Arabidopsis. J Exp Bot. 2014;65:871-84.

26. Zhou J, Jiao F, Wu Z, Li Y, Wang X, He X, Zhong W, Wu P. OsPHR2 is involved in phosphate-starvation signaling and excessive phosphate accumulation in shoots of plants. Plant Physiol. 2008:6:1673-86.

27. Guo M, Ruan W, Li C, Huang F, Zeng M, Liu Y, Yu Y, Ding X, Wu Y, Wu Z. Integrative comparison of the role of the PHOSPHATE RESPONSE1 subfamily in phosphate signaling and homeostasis in rice. Plant Physiol. 2015;168:1762-76.

28. Ruan W, Guo M, Wu P, Yi K. Phosphate starvation induced OsPHR4 mediates pi-signaling and homeostasis in rice. Plant Mol Biol. 2016;93:327-40.

29. Feng H, Yan M, Fan X, Li B, Shen Q, Miller AJ, Xu GH. Spatial expression and regulation of rice high-affinity nitrate transporters by nitrogen and carbon status. J Exp Bot. 2011;62:2319-32.

30. Yan M, Fan X, Feng H, Miller AJ, Shen Q, Xu G. Rice OsNAR2.1 interacts with OsNRT2.1, OsNRT2.2 and OsNRT2.3a nitrate transporters to provide uptake over high and low concentration ranges. Plant Cell Environ. 2011;34:1360-72.

31. Tang Z, Fan X, Li Q, Feng H, Miller AJ, Shen Q, Xu G. Knockdown of a rice stelar nitrate transporter alters long-distance translocation but not root influx. Plant Physiol. 2012;160:2052-63.

32. Araújo OJL, Pinto MS, Sperandio MVL, Santos LA, Stark EMLM, Fernandes MS, dos Santos AM, de Souza SR. Expression of the genes OsNRT1.1, OsNRT2. 1, OsNRT2.2, and kinetics of nitrate uptake in genetically contrasting rice varieties. Am J Plant Sci. 2015;6:306-14. 
33. Fan X, Tang Z, Tan Y, Zhang Y, Luo B, Yang M, Lian XM, Shen QR, Miller AJ $\mathrm{Xu} \mathrm{GH}$. Overexpression of a $\mathrm{pH}$-sensitive nitrate transporter in rice increases crop yields. Proc Natl Acad Sci U S A. 2016b;113:7118-23.

34. Kumar A, Kaiser BN, Siddiqi MY, Glass ADM. Functional characterisation of OsAMT1.1 overexpression lines of rice, Oryza sativa. Funct Plant Biol. 2006;33: 339-46.

35. Ranathunge K, El-kereamy A, Gidda S, Bi Y-M, Rothstein SJ. AMT1;1 transgenic rice plants with enhanced $\mathrm{NH}_{4}{ }^{+}$permeability show superior growth and higher yield under optimal and suboptimal $\mathrm{NH}_{4}{ }^{+}$conditions. J Exp Bot. 2014;65:965-79.

36. Bao A, Liang Z, Zhao Z, Cai H. Overexpressing of OsAMT1-3, a high affinity ammonium transporter gene, modifies rice growth and carbon-nitrogen metabolic status. Int J Mol Sci. 2015:16:9037-63.

37. Klein D, Morcuende R, Stitt M, Krapp A. Regulation of nitrate reductase expression in leaves by nitrate and nitrogen metabolism is completely overridden when sugars fall below a critical level. Plant Cell Environ. 2000; 23:863-71

38. Pant BD, Musialak-Lange M, Nuc P, May P, Buhtz A, Kehr J, Walther D, Scheible W-R. Identification of nutrient-responsive Arabidopsis and rapeseed microRNAs by comprehensive real-time PCR profiling and small RNA sequencing. Plant Physiol. 2009:150:1541-55.

39. Kant S, Peng M, Rothstein SJ. Genetic regulation by NLA and MicroRNA827 for maintaining nitrate-dependent phosphate homeostasis in Arabidopsis. PLoS Genet. 2011;7:e1002021.

40. Medici A, Marshall-Colon A, Ronzier E, Szponarski W, Wang R, Gojon A Crawford NM, Ruffel S, Coruzzi GM, Krouk G. AtNIGT1/HRS1 integrates nitrate and phosphate signals at the Arabidopsis root tip. Nat Commun. 2015;6:6274

41. Yan $Y$, Wang $H$, Hamera S, Chen X, Fang R. miR444a has multiple functions in the rice nitrate-signaling pathway. Plant J. 2014;78:44-55.

42. Cerutti T, Delatorre CA. Nitrogen and phosphorus interaction and cytokinin: responses of the primary root of Arabidopsis thaliana and the pdr1 mutant. Plant Sci. 2013;198:91-7.

43. Schlüter U, Mascher M, Colmsee C, Scholz U, Bräutigam A, Fahnenstich H, Sonnewald U. Maize source leaf adaptation to nitrogen deficiency affects not only nitrogen and carbon metabolism but also control of phosphate homeostasis. Plant Physiol. 2012;160:1384-406.

44. Hachiya T, Sakakibara H. Interactions between nitrate and ammonium in their uptake, allocation, assimilation, and signaling in plants. J Exp Bot. 2017 68:2501-12.

45. Piffanelli $P$, Droc $G$, Mieulet $D$, Lanau $N$, Bès $M$, Bourgeois $E$, Rouvière $C$, Gavory F, Cruaud C, Ghesquière A, et al. Large-scale characterization of Tos17 insertion sites in a rice T-DNA mutant library. Plant Mol Biol. 2007;65: 597-601.

46. Hochholdinger F, Zimmermann R. Conserved and diverse mechanisms in root development. Curr Opin Plant Biol. 2008;11:70-4.

47. Steffens B, Rasmussen A. The physiology of adventitious roots. Plant Physiol. 2016;170:603-17.

48. Sauter M. Root responses to flooding. Curr Opin Plant Biol. 2013;16:282-6.

49. Kiba T, Krapp A. Plant nitrogen acquisition under low availability: regulation of uptake and root architecture. Plant Cell Physiol. 2016;57:707-14.

50. Sun C-H, Yu J-Q, Hu D-G. Nitrate: a crucial signal during lateral roots development. Front Plant Sci. 2017:8:485.

51. De Smet I, Tetsumura T, De Rybel B, Frei dit Frey N, Laplaze L, Casimiro I, Swarup R, Naudts M, Vanneste S, Audenaert D. Auxin-dependent regulation of lateral root positioning in the basal meristem of Arabidopsis. Development. 2007;134:681-90.

52. Laskowski M, Grieneisen VA, Hofhuis H, ten Hove CA, Hogeweg P, Marée AFM, et al. Root system architecture from coupling cell shape to auxin transport. PLoS Biol. 2008;6:e307.

53. Mai CD, Phung NTP, To HTM, Gonin M, Hoang GT, Nguyen KL, Do VN, Courtois B, Gantet P. Genes controlling root development in rice. Rice. 2014;7:30.

54. Krouk G, Lacombe B, Bielach A, Perrine-Walker F, Malinska K, Mounier E, Hoyerova K, Tillard P, Leon S, Ljung K. Nitrate-regulated auxin transport by NRT1.1 defines a mechanism for nutrient sensing in plants. Dev Cell. 2010; 18:927-37.

55. Bouguyon E, Brun F, Meynard D, Kubeš M, Pervent M, Leran S, Lacombe B, Krouk G, Guiderdoni E, Zažímalová E, et al. Multiple mechanisms of nitrate sensing by Arabidopsis nitrate transceptor NRT1.1. Nat. Plants. 2015;1:15015.

56. Miller AJ, Fan X, Orsel M, Smith SJ, Wells DM. Nitrate transport and signalling. J Exp Bot. 2007;58:2297-306.
57. Lima JE, Kojima S, Takahashi H, von Wiren N. Ammonium triggers latera root branching in Arabidopsis in an AMMONIUM TRANSPORTER1;3dependent manner. Plant Cell. 2010;22:3621-33.

58. Miller AJ, Cramer MD. Root nitrogen acquisition and assimilation. Plant Soil. 2004:274:1-36

59. Bloom AJ, Sukrapanna SS, Warner RL. Root respiration associated with ammonium and nitrate absorption and assimilation by barley. Plant Physiol. 1992;99:1294-301.

60. Kronzucker HJ, Siddiqi MY, Glass ADM, Kirk GJD. Nitrate-ammonium synergism in rice. A subcellular flux analysis. Plant Physiol. 1999;119:1041-5.

61. Sun H, Tao J, Liu S, Huang S, Chen S, Xie X, Yoneyama K, Zhang Y, Xu G. Strigolactones are involved in phosphate- and nitrate-deficiency-induced root development and auxin transport in rice. J Exp Bot. 2014;65:6735-46.

62. Fan X, Naz M, Fan X, Xuan W, Miller AJ, Xu G. Plant nitrate transporters: from gene function to application. J Exp Bot. 2017:68:2463-75.

63. Fan X, Feng H, Tan Y, Xu Y, Miao Q, Xu G. A putative 6-transmembrane nitrate transporter OsNRT1.16 plays a key role in rice under low nitrogen. J Integr Plant Biol. 2016;58:590-9.

64. Xia X, Fan X, Wei J, Feng H, Qu H, Xie D, Miller AJ, Xu G. Rice nitrate transporter OsNPF2.4 functions in low-affinity acquisition and long-distance transport. J Exp Bot. 2015;66:317-31.

65. Shin S-Y, Jeong JS, Lim JY, Kim T, Park JH, Kim J-K, Shin C. Transcriptomic analyses of rice (Oryza sativa) genes and non-coding RNAs under nitrogen starvation using multiple omics technologies. BMC Genomics. 2018:19:532.

66. Livak KJ, Schmittgen TD. Analysis of relative gene expression data using real-time quantitative PCR and the $2^{-\Delta \Delta C}$ method. Methods. 2001:25:402-8.

67. Bradstreet RB. Kjeldahl method for organic nitrogen. Anal Chem. 1954;26:185-7
Ready to submit your research? Choose BMC and benefit from:

- fast, convenient online submission

- thorough peer review by experienced researchers in your field

- rapid publication on acceptance

- support for research data, including large and complex data types

- gold Open Access which fosters wider collaboration and increased citations

- maximum visibility for your research: over $100 \mathrm{M}$ website views per year

At BMC, research is always in progress.

Learn more biomedcentral.com/submissions 